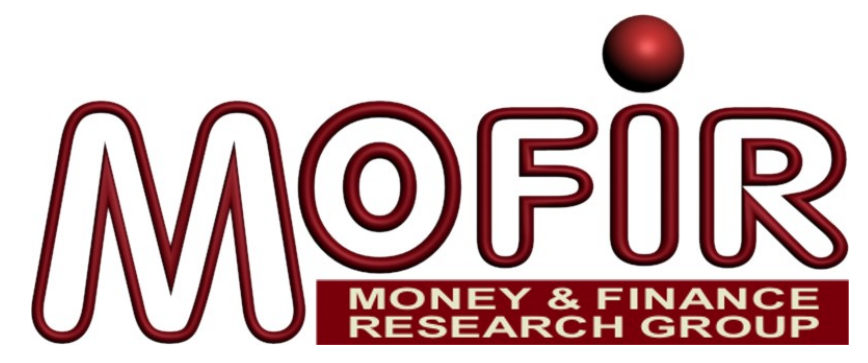

\title{
Competition and Relationship Lending: FRIENDS OR FoEs?
}

ANDREa F. Presbitero

Università Politecnica delle Marche, Department of Economics $M o F i R$

CeMaFiR

Alberto ZaZzaro

Università Politecnica delle Marche, Department of Economics $M o F_{I} R$

CFEPSR

MoFiR working paper $\mathrm{n}^{\circ} 13$

January 2009 


\title{
Competition and Relationship Lending: Friends or Foes?
}

\author{
Andrea F. Presbitero* Alberto Zazzaro
}

February 23, 2010

\begin{abstract}
Recent empirical findings by Elsas (2005) and Degryse and Ongena (2007) document a U-shaped effect of market concentration on relationship lending which cannot be easily accommodated by the investment and strategic theories of relationship lending. In this paper, we suggest that this non-monotonicity can be explained by looking at the organizational structure of local credit markets. We provide evidence that marginal increases in interbank competition are detrimental to relationship lending in markets where large and out-of-market banks are predominant. On the contrary, where relational-based lending technologies are already widely in use in the market by a large group of small mutual banks, an increase in competition may drive banks to further cultivate their extensive ties with customers.
\end{abstract}

JEL Classification: G21, L11

Key words: interbank competition, market organizational structure, relationship lending.

\footnotetext{
${ }^{*}$ Corresponding Author, Department of Economics - Università Politecnica delle Marche (Italy), Money and Finance Research group (MoFiR) and Centre for Macroeconomic and Finance Research (CeMaFiR). E-mail: a.presbitero@univpm.it; personal webpage: http://utenti.dea.univpm.it/presbitero/. Alberto Zazzaro is affiliated at the Department of Economics - Università Politecnica delle Marche (Italy), Money and Finance Research group (MoFiR) and CFEPSR. E-mail: a.zazzaro@univpm.it; personal webpage: http://utenti.dea.univpm.it/zazzaro/. We warmly thank Philip Strahan and two anonymous referees for very constructive comments on a previous version of the paper. We also wish to thank Iftekar Hasan, Francesco Trivieri and participants at the "XVIII International Tor Vergata Conference on Banking and Finance" (Rome) for helpful suggestions.
} 


\section{Introduction}

Even if the banking industry is going global, relationship lending is still perceived as an essential feature of small business finance, not only in the European or Japanese bankbased system, but also in market-oriented systems, such as the US. The bulk of the literature focuses on the effects of exclusive bank-firm ties on lending conditions, while relatively few contributions have investigated what influences relationship lending, and particularly how credit market competition affects bank orientation (transactional versus relational lending).

On the theoretical level, the effect of competition on bank orientation is ambiguous. For those who emphasize the investment nature of relationship lending it is natural to argue that competition and relational lending are die-hard foes. Market power is a necessary condition for banks to extract the informational rent generated by investing specific resources in the relationship with borrowers. Only when exit options for borrowers are limited may banks have an incentive to acquire costly private information on their clients, since they could share surpluses intertemporally, subsidizing credit-constrained firms at the beginning of the relationship and extracting the rent later (Sharpe, 1990; Rajan, 1992; Petersen and Rajan, 1995; von Thadden, 2004; Ogura, 2009). The empirical predictions of the investment theory of relationship lending are that extensive bank-firm ties and relational-based lending to small businesses are more commonly found when the local credit market is more concentrated, regardless of the type of locally-operating banks.

By contrast, once one abandons the assumption of homogeneity of banks or lending technologies and considers the strategic nature of relationship lending, competition and relational lending may be proved to be friends. Fierce competition from out-of-market banks (or in the arm's length market) may steer local banks to orientate their activities towards small, proximate and informationally opaque borrowers, boosting relational lending. In this way they can create a competitive edge that helps insulate themselves from pure price competition of outside banks (Boot and Thakor, 2000; Yafeh and Yosha, 2001; Dell'Ariccia and Marquez, 2004; Hauswald and Marquez, 2006). The empirical implications of the strategic theory of relationship lending is that greater competition in local credit markets can strengthen the exclusive ties between banks and firms and drive banks to increase loans to opaque borrowers, especially when competition is led by large banks, headquartered at a distance from the market.

The applied literature on the effects of interbank competition on bank orientation is somewhat limited and inconclusive. Empirical support for the investment theory of relationship lending is provided, for example, by Petersen and Rajan (1995), Fischer (2000) and recently by Ogura $(2007,2009)$. The former, using data on the US small firms, found that young firms in concentrated markets receive more credit and pay lower interest rates than similar firms in competitive markets, with these differences vanishing as firms get older. In a similar vein, Ogura (2009) found that inside banks in the USA (banks holding the majority of a firm's total checking account balances for more than one year) are willing to charge lower interest rates to young firms only if they operate in concentrated credit markets, thereby having the opportunity to establish an informational advantage over rivals. Such findings were broadly confirmed by Fischer (2000) for the German case, suggesting that competitive pressures in local credit markets discourage banks from acquiring costly information on opaque borrowers. More direct evidence is 
provided by Ogura (2007) who found that, in Japan, the number of competing banks and other measures of market competition are negatively correlated with the likelihood of lending on a relational basis which in turn increases credit availability for new firms.

By contrast, Neuberger et al. (2008) found only a weak or insignificant correlation between market concentration and relationship lending for Swiss small firms, while, consistent with the strategic theory of relationship lending, Memmel et al. (2007) found that, in Germany, competition in local credit markets is positively associated with relationship lending and that small banks are more likely to act as a relationship lender.

None of these studies, however, investigates the possibility that interbank competition has heterogeneous effects on relationship lending, depending on the structure of the local credit market. Influential steps in this direction were recently made by Elsas (2005) and Degryse and Ongena (2007), who explicitly allow for non-monotonic effects of market concentration on relationship lending. Elsas (2005) considers a sample of 122 large German firms borrowing from five major German banks, and considers a bank-firm rapport being relational on the basis of the banks' self-assessment of the Hausbank status. His findings indicate the existence of a U-shaped relationship between the Herfindahl-Hirschman index (HHI) of the local credit market at the registered head office of a firm (computed in terms of bank branches) and the likelihood of a relational bank-firm tie. Where the concentration of the credit market is low, the probability of a bank assuming Hausbank status decreases with a marginal increase in concentration. By contrast, where markets are very concentrated, a further increase in HHI raises the probability of a bank being the firm's Hausbank.

Degryse and Ongena (2007) build on the Elsas study, but adopt more objective measures of bank orientation, which reflect the duration and scope of the relationship, and rely on a much larger dataset of Belgian SMEs borrowing from a large national bank. Their findings confirm the U-shaped relationship between market concentration and the likelihood of bank branches engaging in relationship lending, although the vast majority of firms in their sample are located in postal zones where the correlation is negative. Moreover, the non-monotonic effect of market concentration is robust to control for the presence in the local credit market of banks with multiple contacts across other locations and for the distance of borrowers from both the lending branch and rival banks.

However, neither the investment nor the strategic theory of relationship lending predicts a U-shaped effect of market concentration (or competition) on the relational orientation of banks ${ }^{1}$. Moreover, Elsas (2005) and Degryse and Ongena (2007) fail to devise a complete explanation of why the strategic theory of relationship lending would hold for poorly concentrated market while the investment theory would hold for highly concentrated markets.

In this paper, we suggest that the non-monotonic effect of market concentration on relationship lending is not due to the degree of concentration per se, but to the interplay between market concentration and the type of competitors operating in the local credit market. More precisely, our research hypothesis is that what prevails between the investment and the strategic theories of relationship lending depends on the organizational structure of the local banking system. When the credit market is dominated by highly

\footnotetext{
${ }^{1}$ On the contrary, the models developed by Dinc (2000) and Yafeh and Yosha (2001) predict that banks' investments in relationship lending reach their maximum with an intermediate number of banks and an intermediate level of competition.
} 
hierarchical (large and functionally distant ${ }^{2}$ ) banks, market concentration favors close and extensive bank-firm ties. On the contrary, when the majority of branches belong to small, non-hierarchical local banks, it is stronger interbank competition (i.e., lower market concentration) which promotes relationship lending. The intuition for this conjecture is simple and has to do with the comparative advantages hierarchical and non-hierarchical banks can exploit when competition is tough (Berger and Udell, 2006). The former type of institution has a comparative advantage in transaction-oriented lending technologies, like financial statement lending, credit scoring or asset-based lending, due to scale economies in collecting, processing and assessing hard information, while it is disadvantaged at relationship lending due to organizational diseconomies in dealing with soft information. For opposite reasons, small institutions with few layers of management are comparatively advantaged at using subjective and non-codified information and establishing close lending relationships with information-intensive borrowers. In this view, greater interbank competition should encourage or discourage the use of relational-oriented technologies depending on the type of lending institution which predominates in the local market.

In what follows, we provide evidence for a large sample of small and medium sized Italian manufacturing firms, consistent with our hypothesis reconciling the investment and the strategic theories of relationship lending. Once we introduce in a regression model of relationship lending the interaction terms between market concentration and different measures of size, localism and distance of locally-operating bank branches, the U-shaped effect of HHI vanishes, while the non-linear effect of competition is driven by the organizational structure of the local banking system: competition and relationship lending are friends or foes according to who are the major competitors, small cooperative banks or large and distant banks.

The rest of the paper is organized as follows. In the next section, we discuss the theory laying behind the interplay of competition and organizational structure of banking systems in shaping bank-firm relationships. In Section 3, we describe our dataset, the estimation methodology and the variables. In Sections 4 and 5, we discuss the econometric results for the basic model and various robustness exercises. Finally, in Section 6 we draw some concluding remarks.

\section{Bank organization, competition and orientation: background theory and evidence}

Well received theoretical arguments indicate that bank size and organizational design influence its lending orientation and asset allocation (soft-information-based versus hardinformation-based activities). The idea is that large and geographically dispersed banks are highly hierachized institutions, and that hierarchiness is associated with organizational diseconomies which place these banks at a disadvantage with respect to small, local banks in lending to information-intensive borrowers on a relational basis (Berger et al., 1999; Berger and Udell, 2002; Stein, 2002). To the extent that relationship lending relies heavily on non-codified information, only available to opportunistic loan officers at the local level, the use of this lending technology entails serious communication and

\footnotetext{
${ }^{2}$ By functional distance, we mean the distance between local branches (or subsidiaries) and the decisional centre (typically the headquarter) of their parent bank (Alessandrini et al., 2005).
} 
agency problems across the bank organizational layers which may advise large and distant banks against it (Aghion and Tirole, 1997; Garicano, 2000; Scharfstein and Stein, 2000). On the one hand, a career-conscious loan officer anticipates that bank managers at the parent bank are unable to properly appreciate soft information he/she may gain during the relationship with borrowers and reduces his/her effort in producing it, while overinvesting in hard and verifiable information (Milbourn et al., 2001). On the other hand, in order to avoid the formation of information rent and mitigate agency problems, loan officers are frequently asked to rotate within large banks and are discouraged from basing lending decisions on soft information (Hertzberg et al., 2009).

Empirical evidence is broadly consistent with such theoretical predictions. A great number of studies, concerning different countries, document that big banks devote to small business lending a lower share of their resources (Berger and Udell, 1996; Sapienza, 2002; Degryse et al., 2009b) and that, in turn, small firms are more likely to borrow from small banks (Berger et al., 2005; Uchida et al., 2008). Other studies show that functionally distant banks tend to pick up informationally transparent firms and are less prone to assist firms facing financial distress (Carter and McNulty, 2005; Mian, 2006; Alessandrini et al., 2008; Canales and Nanda, 2008; Benvenuti et al., 2009; Micucci and Rossi, 2009). Moreover, small firms located in markets with predominantly functionally distant banks are more likely to be credit-rationed and less inclined to introduce new technologies and products (Alessandrini et al., 2009a,b).

A relatively small number of studies focus on the effect of bank size, distance and ownership structure on the lending technology. Cole et al. (2004) and Scott (2004) found that large banks in the USA rely heavily on hard information about firm financial statements in deciding on loan approvals, while small banks base their decisions also on soft information informally gathered through repeated face-to-face contacts with borrowers. In this vein, Frame et al. (2001) and Akhavein et al. (2005) reported that large, centralized banking organizations are more likely to use automated credit scoring technologies in small business lending, while Berger et al. (2005) found that small banks are better at using soft information as they lend at a lower distance and are more likely to employ personal modes of communication with their borrowers. The role of hierachical distance in influencing the importance of soft information in lending approval decisions is documented by Liberti and Mian (2009). In particular, focusing on the case-study of a large multinational bank operating in Argentina, they found that the soft-information sensitivity of credit facility is significantly lower when the credit line is approved at higher hierarchical levels, geographically distant from the office that collected information on the borrower. Finally, Angelini et al. (1998) and Delgado et al. (2007) showed that the bank lending orientation is influenced by its ownership structure, as savings and cooperative banks tend to specialize in small borrowers.

Looking directly at relationship lending, Berger et al. (2005) documented that credit relationships are longer-lasting and more exclusive when the lending bank is small-sized. Uchida et al. (2008) validated these results in the Japanese context, by showing that small banks tend to have closer ties and repeated contacts with their borrowers and lend at a shorter distance than large banks. Lastly, Angelini et al. (1998), Uzzi (1999) and Neuberger et al. (2008) found that localism and cooperative ownership is also positively associated with the relational orientation of banks due to the deepply embedded ties with the local economy, and the peer nexus between lenders and borrowers. 
If it is true that hierarchical and non-hierarchical banks have a comparative advantage in transactional and relational lending, respectively, then it is conceivable to expect that they will react to stronger competition by concentrating efforts and resources on their favorite lending technology. Therefore, if the local credit market is predominantly populated by hierarchical (large and distant) banks, interbank competition and relationship lending should be observed to be negatively associated. On the contrary, if the organizational structure of the local credit market is made up by non-hierarchical (small, local and cooperative banks), relationship lending should increase with competition. However, as far as we know, empirical evidence on the effects of the interplay of bank organizational structure and interbank competition in determining lending orientation is virtually lacking. Partial exceptions are Brevoort and Hannan (2004), Canales and Nanda (2008), Carbó-Valverde et al. (2009) and Degryse et al. (2009a) who provide some useful indications consistent with the strategic use of bank orientation.

Brevoort and Hannan (2004) documented that the importance of physical proximity between banks and borrowers located in the US metropolitan areas has increased over the years 1997 to 2001, immediately after the Interstate Banking and Branching Efficiency Act was passed to remove interstate branching restrictions to banks and bank holdings and increase interbank competition (Rice and Strahan, 2009). If physical proximity entails informational proximity, Brevoort and Hannan (2004, p. 25) note, this finding is "consistent with the notion that as competition increases from lenders located outside the market, local lenders reallocate resources toward loans in which they enjoy a locational advantage".

In a similar vein, Degryse et al. (2009a) showed that the more rival banks are hierarchically organized and the more competitors' branches have real authority, the lower is the geographical reach of the lending branches and the greater is their orientation to physically proximate borrowers.

Finally, more in line with our empirical approach, Canales and Nanda (2008) investigate how centralized and decentralized (in terms of branch managers autonomy) banks in Mexico respond to interbank competition in local credit markets. The results they report indicate that where competition is harsher, decentralized banks tend to reallocate resources in favor of small and micro enterprises by reducing interest rates and increasing loans to this category of borrower. Similarly, Carbó-Valverde et al. (2009) found that when local credit markets are more contestable (i.e. the entrance of new competitors is greater) the negative impact of competition on credit availability to small businesses decreases.

\section{Empirical setup}

\subsection{Data}

The analysis is carried out on the eighth and ninth waves of the Survey on Manufacturing Firms ("Indagine sulle Imprese Manifatturiere") published by the Unicredit Group (formerly Capitalia). The Unicredit surveys collect a large set of information on a representative sample (stratified by firm size, industry sector and firm location) of Italian SMEs with 11-500 employees and the universe of firms with more than 500 employees over the period 1998-2003. From the original sample of 8,969 firms we exclude a number 
of observations for which there are missing values for relevant variables, such as location, industry and number of employees. We also control for consistency in some answers, especially concerning the number of banking relationships and the share of banking credit supplied by the main bank. Finally, we focus on SMEs, so that we drop from the sample very large firms with more than 500 employees. Thus, we end up with 4,121 observations.

Firm-level data are merged with indicators of credit market structure at the provincial level measured in the first year of the survey and calculated using Bank of Italy data on the number and geographical diffusion of bank branches ${ }^{3}$. Taking the province as the appropriate size of local credit markets is consistent with recent literature on the Italian banking system (Herrera and Minetti, 2007; Benfratello et al., 2008; Alessandrini et al., 2009b), given that, according to the Bank of Italy data, more than 90 percent of credit granted involves banks and firms located in the same province.

Finally, information on the asset size of banks was taken from Bilbank, a data set produced by the Italian Association of Bankers (ABI) collecting the balance sheets of Italian banks, while data on provincial value added and population are drawn from the National Institute of Statistics (ISTAT) database.

\subsection{Empirical models and methodology}

Relationship lending is a complex phenomenon, difficult to measure. In the empirical literature it has been proxied by different aspects, such as the firms' number of banks, the length and scope of the relationship, the share of loans supplied by the main bank and the lender's status of Hausbank.

Unlike Elsas (2005) and Degryse and Ongena (2007), our dataset is at the firm level and therefore we cannot use the Hausbank status as a measure of relationship lending. However, referring to the German case, Elsas (2005) showed that the bank's share of firm's total debt is significantly associated with the bank being a relationship lender, that is, with the self-assessment of the bank being a Hausbank, with good access to exclusive information about the firm and a good capacity to influence its management. By contrast, the duration of the bank-firm relationship is not related to the Hausbank status, while the number of banks seems to negatively affect the availability of information about the firm.

Following this indication, in this paper we measure relationship lending by the share of banking credit supplied to the firm by its main bank (FINSHARE $)^{4}$. Moreover, as robustness, we also build a yes-or-no indicator of banks' relational orientation, RELBANK, that assumes the value of one if the firm obtains at least one fifth of bank credit from its main bank and has credit lines with no more than five banks, and the value of zero otherwise (see section 5.2) .

\footnotetext{
${ }^{3}$ Italy is currently divided into 107 provinces, which are grouped into 20 administrative regions. However, since some provinces were recently constituted, we use the old classification of 95 provinces.

${ }^{4}$ As a referee has noticed, not only banks decide on their orientation towards relationship lending, but firms do so as well. In this vein, FINSHARE might capture the firm rather than the bank orientation. While this ambigiguity poses interpretation problems, broadly shared across the literaure on relationship lending, in our model the problem of endogeneity is mitigated by the fact that the key dependent variables are at the market level.

${ }^{5}$ The exact questions posed to firms in the Unicredit Survey re: (i) "Considering the bank debt equal to 100 at the end of (the last year of the survey), what was the share held by the main bank?"';
} 
The impact of competition on the intensity of bank-firm ties is expressed as a function of firm-specific characteristics, the degree of concentration and the organizational structure of local credit markets, and some features of local economies. We model the non-monotonic effects of market concentration on relationship lending, augmenting the model with the squared term of market concentration and with the interaction terms between market concentration and other indicators of credit market organizational structure:

$$
\begin{aligned}
\text { FINSHARE }_{i j}= & f\left(H H I_{j}, H H I_{j}^{2}, O R G M K T S T R C_{j},\right. \\
& \left.H H I \times O R G M K T S T R C_{j}, \text { FIRM }_{i}, \text { PROV }_{j}\right)
\end{aligned}
$$

where subscripts $i$ and $j$ indicate respectively the firm and the province where it is officially headquartered; HHI is the Herfindahl-Hirschman index; ORGM KTSTRC are the market organizational structure variables; FIRM and PROV are firm- and provinciallevel control variables.

We estimate equation (1) by using the fractional logit estimator. Indeed, since the share of debt borrowed from the main bank is bounded between zero and one, the OLS linear regression is unsuitable for the FINSHARE model because it cannot guarantee that the predicted values lie in the unit interval, like for binary data models. The standard solution of applying a logistic transformation to the dependent variable presents two main drawbacks. First, a linear model on the log-odds ratio could be estimated only when the dependent variables is strictly between zero and one ${ }^{6}$. Second, once the logistic transformation is applied, intensive computation is required to calculate $E(y \mid \mathbf{x})$. An alternative solution we follow in this paper, which does not require data adjustments and allows for direct estimation of the conditional expectation, is the fractional logit model proposed by Papke and Wooldridge (1996). The fractional logit model consists in modeling the expected values of the share of the firm's debt held by the main bank as follows:

$$
E\left(F I N S H A R E_{i} \mid \mathbf{X}_{\mathbf{i}}\right)=\frac{\exp \left(\mathbf{X}_{\mathbf{i}} \hat{\beta}\right)}{\left[1+\exp \left(\mathbf{X}_{\mathbf{i}} \hat{\beta}\right)\right]}
$$

where $\mathbf{X}_{\mathbf{i}}$ is the vector of explanatory variables, including firm-specific characteristics and banking market indicators. The parameters are estimated maximizing the Bernoulli log-likelihood function in order to get the consistent Bernoulli quasi-maximum likelihood estimator $\hat{\beta}^{7}$.

Despite the limitations stated above, for robustness we estimate equation (1) also with the simpler linear model, which has the advantage of allowing for the interpretation of estimated coefficients as marginal effects.

Since our dependent variable is at the firm level, while key explanatory variables (i.e., interbank competition and organizational structure of banking systems) are at the market

(ii) "State the number of banks with which the firm had a credit relationship in (the last year of the survey)"' (Capitalia, 2005).

${ }^{6}$ If $y=1$ or $y=0, \log [y /(1-y)]$ does not exist, and any procedure to adjust for the extreme values presents serious problems of approximation.

${ }^{7}$ For applications of the fractional logit model to firm-level data see, amongst others, Hausman and Leonard (1997) and Wagner (2001). 
level, the assumption of independently distributed disturbances is not appropriate. In particular, under the more realistic assumption that the relationship lending indicator and the residual are independent across firms but are correlated across observations in the same province, the OLS standard errors can be proved to be biased downwards (Moulton, 1990; Petersen, 2009). Hence, we correct the variance-covariance matrix by clustering the standard errors at the provincial level ${ }^{8}$.

\subsection{Variables}

\subsubsection{Market concentration and organisational structure variables}

We use four different measures of the structure of local credit markets at the provincial level. The degree of concentration of provincial credit markets is measured by the standard Herfindhal-Hirschman index (HHI) calculated as the sum of the squared share of bank branches owned by each bank operating in the province ${ }^{9}$. Although the HHI index is not the only possible measure of market concentration, it remains the one most commonly used by both economists and antitrust regulators all around the world (Cetorelli, 1999; Cetorelli and Strahan, 2006), and its adoption allows us to directly compare our findings with the existing literature on competition and relationship banking (Elsas, 2005; Degryse and Ongena, 2007). However, the new empirical industrial organization literature has cast doubts on structural market concentration indexes as a measure of interfirm competition and suggests the use of model-based indicators, like the Lerner index or the Panzar-Rosse $H$ statistic (Panzar and Rosse, 1987; Bresnahan, 1989), which take into account the observed firms' behavior. Therefore, for robustness we also reproduce our results using the $H$-statistic built at the provincial level (see Section 5.4).

The size and organizational structure of credit markets is measured by three different indicators which should capture the propensity of locally-operating banks to engage in relationship lending:

1. the functional distance of the local banking system from the local borrowers, computed as the number of branches in province weighted by the logarithm of 1 plus the kilometric distance between the province of the branch and the province where the parent bank is headquartered, over the total of branches in province $(F-D I S T A N C E)^{10}$;

2. the size structure of the local banking system, computed as the ratio of branches owned by large banks to the total, non-weighted number of branches operating in

\footnotetext{
${ }^{8}$ For robustness, we replicated all regressions with robust standard errors for heteroskedasticity excluding correction for cluster correlation and we found virtually identical results (they are available upon request).

${ }^{9}$ The index is standardized between 0 and 10 in order to have more readable coefficients.

${ }^{10}$ More precisely, the functional distance of the banking system from province $j$ is reckoned as:

$$
F-\operatorname{DISTANCE} E_{j}=\frac{\sum_{b=1}^{B_{j}}\left[\text { Branches }_{j, b} \times \ln \left(1+K M_{j, z_{b}}\right)\right]}{\sum_{b=1}^{B_{j}} \text { Branches }_{j, b}}
$$

where $B_{j}$ is the number of banks operating in province $j$, Branches $_{j, b}$ is the number of branches belonging to bank $b$ in province $j$, and $z_{b}$ is the province where the headquarter of bank $b$ is located (Alessandrini et al., 2009b).
} 
each province ( $L A R G E B A N K S$ ), where a bank is classified as large if its total assets are more than 26 billion euros at 2003 prices $^{11}$;

3. the share of branches held by mutual banks in each province, which is a measure of the degree of localism and social embeddedness of provincial credit markets (MUTUAL BANKS).

We build banking system variables using information on the geographical distribution of branches of all the Italian banks. To partially take into consideration possible issues of reverse causality, they are calculated in the first year of each survey ${ }^{12}$. In 1998, there were 926 banks operating in Italy with a network of 26,301 branches; in 2001 these numbers were 834 and 29,300, respectively. Of these branches, in 1998 (2001), 11,528 (11,951) belonged to out-of-province banks, $9,295(11,128)$ to large banks and 2,800 $(3,083)$ to mutual banks.

At the aggregate level, we expect the coefficients on the interaction terms $H H I \times$ $F-D I S T A N C E$ and $H H I \times L A R G E B A N K S$ to be positive. Following the investment theory of relationship lending, the intuition is that a low interbank competition is a necessary condition to orientate large and functionally distant banks to lend on a relational basis. These types of banks have a competitive advantage in offering transactional products with respect to small, local banks, while they are at a disadvantage in relationship lending (Berger and Udell, 2002). Therefore they find it rewarding to engage in relationship lending only if market power allows them to extract additional future rents from investing resources in building extensive ties with borrowers.

However, by increasing the incidence of small mutual banks with a local vocation and comparative advantages in using soft information, it is more likely that, at the aggregate level, competition goes hand-in-hand with more relationship lending (i.e., the coefficients on the interaction terms between $H H I$ and MUTUAL BANKS are expected to be negative), consistently with the strategic theory of relationship lending (Dell'Ariccia and Marquez, 2004; Hauswald and Marquez, 2006).

\subsubsection{Control variables}

In model (1) we include a set of standard firm-specific characteristics and indicators of provincial economic development. In particular, we control for: (i) firm's age and age squared, measured by (one plus) the logarithm of the years from its inception $(A G E)$; (ii) the number of workers employed in the firm, divided into four categories $(S I Z E)$; (iii) the riskiness of the firm, measured by the one-year probability of default as computed by the RiskCalc $^{T M}$ Italy model developed by Moody's KMV $(R I S K)^{13}$; (iv) the efficiency of its production process, proxied by a dichotomous variable equal to one for firms which have

\footnotetext{
${ }^{11}$ This is the official definition of large banks adopted by the Bank of Italy. According to the Italian central banks, major banks have assets of over 60 billion euros, while medium banks have assets of between 9 and 26 billion euros. For robustness, we construct alternative measures of LARGE BANKS including also medium banks or limiting the definition to the major banks. See Section 5.3

${ }^{12}$ We check the robustness of our findings taking the credit market variables in the year before the three-year period covered by each survey (results available upon request).

${ }^{13}$ The RiskCalc ${ }^{T M}$ model for one-year risk of default combines firm's financial statement ratios concerning profitability, leverage, debt coverage, growth, liquidity, activity ratios, size (Dwyer et al., 2004). We thank Toni Riti of Unicredit for kindly providing us with the RISK rating variable.
} 
received the international standard ISO 9000 for quality management systems (ISO9000); (v) the firm's degree of innovativeness, measured by a dummy variable which is equal to one for firms that made expenditures on $R \& D$ in the three-year period covered by each survey and zero otherwise $(R \& D)$; (vi) the firm's degree of internationalization, measured by two dummy variables: $E X P O R T$, equal to one when the firm sells part of its production abroad, and OFFSHORE, equal to one for firms realizing part of their production abroad.

Then we add the logarithm of the provincial real per capita value added in the first year of the survey ( $V A L U E A D D E D)$ as a control variable at the provincial level. Since economic and local financial development has proved to be highly correlated in Italy (Lucchetti et al., 2001; Guiso et al., 2004a), the introduction of $V A L U E$ ADDED allows us to identify the true effect of the credit market structure on relationship lending. Finally, in all regressions we include wave and industry dummies to control for possible time and industry-specific effects on relationship lending.

\section{Results}

\subsection{Descriptive analysis}

In Table 1 we report the definition and the sample statistics of the variables used in the regression analysis, while in Figure 1 we plot the kernel density of FINSHARE and the sample distribution of the number of firms' banking relationships, on the basis of which we build the other dependent variable, $R E L B A N K$. Both the distributions are positively skewed. FINSHARE (Panel (a)) has its mode in correspondence of firms collecting around one third of their total bank debt from the main bank. Only 114 firms (1.6 percent of the sample) borrow at least 90 percent of credit from the main bank, while the average (median) share of total debt funded by the main bank is $0.41(0.35)$. Consistently, and in line with the standard evidence on Italy (Ongena and Smith, 2000), Panel (b) shows that multiple lending is a very frequent phenomenon in our sample, while single-bank relationships are very uncommon. Less than one percent of surveyed firms maintain an exclusive relation with a bank, eight percent of firms have credit relationships with two banks, 40 percent with no more than four banks and 42 percent with more than five banks. Finally, the dummy variable $R E L B A N K$ assumes the value of 1 for 57.2 percent of firms in our sample which, at the same time, collect no less than 20 percent of credit from the main bank and have contacts with no more than 5 banks.

The univariate relationship between market concentration and the two alternative measures of relationship lending is clearly non-monotonic. The share of credit supplied to the firm by its main bank and the likelihood of relationship lending $(\operatorname{RELBANK=1)}$ is greater for companies headquartered in provinces where local credit markets exhibit a low or high degree of concentration (Table 2), although the average shares of debt with the main bank across the $H H I$ distribution are not very dissimilar in magnitude.

Finally, in Table 3 we report correlations between the provincial values of $H H I$ and of the organizational structure of the local banking system. As expected, the level of credit market concentration is positively correlated with the presence of out-of-market banks in the market and negatively correlated with the presence of small, mutual banks headquartered in the same province. By contrast, local market concentration is not 
significantly correlated with the share of large banks in the province. Although somewhat surprising, this result is driven by provinces in a single region (Sardinia) where a single local bank (Banco di Sardegna), not included in the group of large banks, opened and acquired a large number of branches during the sample period, thereby increasing $H H I$ and decreasing $L A R G E B A N K S$.

\subsection{The basic model}

In Table 4 we report regression results for our preferred models. Both the fractional logit (columns 1 to 5) and linear (columns 6 to 10) estimates provide qualitatively and quantitatively similar results. The coefficient of the former can be directly interpreted as marginal effects. In the following we will discuss separately the effects of control variables and, in greater depth, of the key banking variables.

\subsubsection{Control variables}

In all specifications, regardless of the econometric methodology we use, coefficients on control variables are fairly robust in sign, value and statistical significance and hence we can comment on them once and for all.

As we expected, the exclusivity of ties with the main bank significantly decreases with the size of the firm as well as with the efficiency of the production process (ISO9000), which could be both considered as proxy of the firm informational transparency. According to the estimates reported in column 1, for very small enterprises (employing between 11 and 20 workers) almost half (45\%) of their banking credit is granted by their main bank, while this share shrinks to about $33 \%$ for medium firms employing between 260 and 500 workers. Firms whose production process is ISO 9000 certified have, all else equal, a value of FINSHARE one percentage point smaller than non-certified firms. By contrast, $A G E$ and $A G E^{2}$ are not statistically associated with the share of firm debt held by the main bank.

Consistent with the descriptive analysis of our sample, companies which invest in $R \& D$ receive a 1.4 percent smaller share of their credit from the main bank ${ }^{14}$. In the same way, firms that operate abroad producing (OFFSHORE) or selling (EXPORT) part of their output raise a lower share of their total debt from their main bank. The effect is somewhat larger for offshoring firms, for which the decrease in FINSHARE is equal to 2.5 percentage points, than for exporting firms. A similar negative impact on the exclusiveness of the bank relationship is produced also by firm's riskiness, even if the economic effect is quite small: FINSHARE for a risky firm (at the third quartile of the sample distribution of $R I S K$ ) is $0.4 \%$ smaller than for a safe firm (at the third quartile of the sample distribution of $R I S K$ ). These results are partially at odds with predictions of the literature on relatioship lending. Theoretically, more risky, innovative and abroadoriented companies should benefit most from close bank ties and intertemporal loan contract design. Moreover, there is evidence showing that relationship lending fosters fims' innovation adoption (Herrera and Minetti, 2007) and internazionalization (De Bonis et al., 2008). However, our findings are consistent with the idea that firms that either

\footnotetext{
${ }^{14}$ Firms investing (not investing) in R\&D have a value of FINSHARE equal to 38 (42) percent, and the difference is statistically significant at the 1 percent level of confidence.
} 
engage in $\mathrm{R} \& \mathrm{D}$ or are active in international markets consist predominantly of solid and transparent firms who are less interested in maintaining exclusive relationships with a single bank (Bond et al., 2003; Alessandrini et al., 2009a), and with the evidence that riskier firms are more likely to mantain long-lasting and wide-ranging relationship with their bank (Degryse and Ongena, 2007) and tend to borrow from a greater number of banks (Cosci and Meliciani, 2002; Guiso and Minetti, 2004).

Finally, as expected, transactional lending is more frequent in richer provinces, where the soundness of the economic and socio-economic structure increases firms' transparency (Ferri and Messori, 2000).

\subsubsection{Market concentration and organizational structure variables}

As regards the variables of interest, in the first and sixth columns we estimate a simple model in which, as in Elsas (2005), the only credit market indicator is the HerfindahlHirschman index of local credit market concentration, added both linearly and squared to allow for possible non-monotonicity. In fact, even after controlling for provincial real value added, we are able to replicate the results found by Elsas (2005) and Degryse and Ongena (2007). The coefficients on $H H I$ and $H H I^{2}$ are jointly significant and, as Figure 2 displays, the relationship between market concentration and FINSHARE is U-shaped, obtaining a minimum at an $H H I$ of 1.37 and 1.38 in the case of, respectively, fractional logit and linear estimations, between the sixth and the seventh decile of its distribution and well below the threshold of 1.8 typically used by the antitrust authorities to identify concentrated markets (Cetorelli, 1999). However, this relationship tends to lose significance once we include other organizational market structure variables (columns 2 and 7 ). When jointly considered, the linear and quadratic terms are significant, but the U-curve has a minimum at $H H I=0.38$ ( 0.40 in the case of the linear model), a value below the fifth percentile of the provincial distribution of HHI and well below the threshold of 1 identifying competitive markets. This implies that the relationship between $H H I$ and FINSHARE can be considered as almost strictly positive, supporting the investment theory of relationship lending. The coefficients on $F-D I S T A N C E$ and MUTUAL BANK have the expected negative and positive signs but they are not significant, probably because of multicollinearity. Finally, LARGE BANK has a positive and significant coefficient. Although somewhat surprising, these findings confirm the idea that size per se is not sufficient to explain the banks' preference for lending technologies and that the profitability of lending to small, opaque borrowers on a relational base is strongly affected by the competitive, institutional and social environments in which large or small banks operate (Berger and Udell, 2006; Berger et al., 2007).

The sensitivity of the effects of market concentration on relationship lending to organizational structure variables clearly indicates that the non-monotonicity of $H H I$ might hide a different sort of heterogeneity due to the type of banks operating locally. Hence, in columns 3-5 and 8-10 we add the interaction terms between HHI and, alternatively, the three indicators of market organizational structure. On the whole, our results suggest that a marginal increase in credit market concentration can positively affect the relational orientation of banks only when the local market is populated by a sufficiently large number of branches owned by large and functionally distant banks, which are at a disadvantage in relationship lending. By contrast, the strong presence of mutual banks, 
which largely adopt relationship-based lending technologies, makes further concentration inimical to relationship lending. These findings reconcile the investment and strategic theory of relationship lending or, rather, they indicate that extensive bank-firm ties tend to develop either where transaction lenders gain enough market power to informationally capture their customers or where relational-based loans can be used as a competitive edge in markets patrolled by local banks.

Going into details, when we interact HHI with $F-D I S T A N C E$, the coefficient on the squared term of market concentration loses statistical significance in favor of the interaction term while the coefficient on $F-D I S T A N C E$ assumes statistical significance (columns 3 and 8). In provinces where the value of $F-D I S T A N C E$ is above (below) 2.8, a value close to the fourth decile of its provincial distribution, the effect of market concentration on FINSHARE is positive (negative). On the contrary, after interacting $H H I$ with $M U T U A L B A N K S$ (column 5), the marginal impact of concentration on FINSHARE appears to be positive only in provinces where the market share of mutual banks is less than 7 percent, which is true in 41 out of 95 provinces over the sample period (it is worth noting that more than half of the firms in the sample are headquartered in those provinces), while it proves negative as long as the degree of localism increases.

Unlike the previous results, the inclusion of the interaction between $H H I$ and the share of large banks (columns 4 and 9) does not wipe out the statistical significance of the quadratic term of market concentration, even if the point estimates provide evidence for a differentiated impact of competition on relationship lending according to the presence of large banks. In fact, in markets where the share of branches owned by large bank is around 15 per cent (the first quartile of the provincial distribution of LARGE BANKS) the convex curve has a minimum in correspondence of a very high value of $H H I(2.16$, above the $90^{\circ}$ percentile), such that the basic relation can be considered negative. On the contrary, for firms located in provinces with a great presence of large banks (29 percent, which corresponds to the third quartile of the distribution of $L A R G E B A N K S$ ) the relation between $H H I$ and FINSHARE is still U-shaped, since the minimum of the U-curve is for a value of $H H I$ (1.33) which is very close to its median. A similar result holds also when $L A R G E B A N K S$ assumes its average value $24 \%$. However, when we consider provinces where the market share of large banks is sufficiently high - greater than 46 percent, as in Turin or Rome (it is worth noting that in our sample one fourth of firms operate in such a market) - the relationship between concentration and relationship lending is strictly positive, since the minimum of the curve occurs for a value of $H H I$ lower than the minimum of its sample distribution.

The results of specifications (3)-(5) are represented in Figure 3. In left-hand diagrams we plot the relation between $H H I$ and FINSHARE when the organizational structure variables are taken at the first quartile of their provincial distribution, while the righthand diagrams are plotted by fixing the value of the organizational structure variables at the third quartile of their distribution. As we stated, once we take into account the type of locally-operating banks, the U-shaped relation between HHI and FINSHARE found by Elsas (2005) and Degryse and Ongena (2007) tends to vanish. Only in panel (d), when we consider the share of large banks' branches in the province and where this is great, does the effect of a marginal decrease in market concentration depend on the initial level of concentration in the province. However, as we have already underlined, this relationship becomes monotone and positive where $L A R G E B A N K S$ is sufficiently 
high, and this happens for a significant number of firms.

To gain some additional insights on the economic significance of the interplay between market concentration and the organizational structure of the local banking system, consider the effect of a shift from competition to concentration in local credit markets on the intensity of relationship lending. In provinces where the banking system is functionally close ( $F-D I S T A N C E$ equal to the first quartile of its provincial distribution), a theoretical shift from the average competitive market $(H H I<1)$ to the average concentrated one $(H H I>1.8)$ lowers the share of credit supplied by the main bank from 40.8 to 39.2 percent ${ }^{15}$. By contrast, the same variation of $H H I$ in provinces whose credit markets are dominated by functionally distant banks $(F-D I S T A N C E$ equal to the third quartile of its provincial distribution) increases the likelihood of strong bank-firm ties from $39.8 \%$ to $43.2 \%$. A similar, but somewhat lower, effect happens when considering bank size. Moving from a competitive to a concentrated credit market reduces the FINSHARE from 40.4 to 39.1 percent in markets with a limited presence of large banks. On the contrary, when large banks predominate ( $L A R G E B A N K S$ equal to the third quartile of its provincial distribution), a shift from competition to concentration would be associated to an increase in the measure of relationship lending from 40.5 to 42 percent. Finally, in local markets where MUTUAL BANKS is equal to $4 \%$ (15\%) a shift from competitive to concentrated markets increases (reduces) FINSH ARE from 40.5 (40.7) to 41.9 (39.6) percent.

\section{Robustness}

We control the validity of our main findings undertaking a number of robustness checks. First, results do not change significantly across different samples and on changing the set of firm-specific control variables. Namely, we limited our analysis to SMEs with less than 250 employees and we controlled for the firms' return on assets, volume of sales, alternative measures of propensity to innovate, juridical status and affiliation to interfirm groups and consortia. On the top of that, we addressed more specific concerns regarding the econometric methodology, the dependent variable, the bank organizational variables and the measure of market competition.

\subsection{Alternative testing for non-linearities}

Throughout the paper we modeled the non-monotonic effect of credit market concentration on relationship lending by adding a quadratic term for $H H I$. However, imposing a quadratic functional form could lead to erroneously accept the hypothesis of a U-shaped relationship, because the estimated minimum point can be outside the data-range and, especially, because the significance of the quadratic term may be driven by a few extreme values. Therefore, we address these concerns in two alternative ways. Firstly, we adopt a less parametric approach, estimating a linear spline with one discontinuity point (Marsh and Cormier, 2002):

\footnotetext{
${ }^{15}$ Recall that $H H I$ is scaled between 0 and 10 , such that the reported variations correspond to the actual threshold of $H H I=1000$ and $H H I=1800$ identified by antitrust authorities to discriminate between competitive, moderately concentrated and concentrated markets.
} 


$$
\begin{aligned}
Y_{i j}= & f\left(H H I_{j},\left(H H I_{j}-H H I_{T}\right) \times I_{T}, O R G M K T S T R C_{j},\right. \\
& \left.F_{R} M_{i}, P_{R O V_{j}}\right)
\end{aligned}
$$

where $I_{T}$ is an indicator function such that:

$$
I_{T}=0 \text { if } H H I_{j}<H H I_{T} \text { and } I_{T}=1 \text { if } H H I_{j}>H H I_{T}
$$

In order to avoid any arbitrariness we chose the threshold $H H I_{T}$ estimating equation (2) by OLS with all possible discontinuity points of $H H I$ and retaining the one which maximizes the overall adjusted $R^{2}$. Following this approach, we can set $H H I_{T}$ at 0.975 , very close to the antitrust threshold separating competitive and concentrated markets and somewhat smaller than the minimum of the U-shaped curve estimated in Table 4. As illustrated by columns 1 and 3 in Table 5, consistent with results from quadratic specification, in competitive markets, fiercer interbank competition is associated with an increase in relationship banking, while in moderately concentrated and in concentrated markets interbank competition is associated with lower values of FINSHARE.

Further confirmation of the presence of a U-shaped relationship between market concentration and our measure of relationship lending is provided by the estimation of a fractional polynomial model with two power terms of HHI (Royston and Sauerbrei, 2008). As reported in Table 5 (columns 2 and 4), among the 44 possible combinations, the best-fitting fractional polynomial powers of $H H I$ are -2 and $+2^{16}$. Figure 4 maps the resulting fit and the $95 \%$ confidence interval, both for the fractional logit (panel (a)) and for the linear model (panel (b)). The inspection of regression results and the diagrams clearly confirm the presence and significance of a U-shaped relation between market concentration and relationship lending.

\subsection{An alternative measure for relationship lending}

In Table 6 we display estimation results of probit and linear probability models by using the indicator variable $R E L B A N K$ as a measure of bank orientation. RELBANK is equal to one when the firm maintains at least $20 \%$ of its bank debt with the main bank and borrows from five or less banks, while it assumes the value of zero when at least one of these conditions are not met. Reported coefficients are the average partial effects (APEs) of exogenous variables. Given the problems related to estimating the marginal effects in non-linear models in which interactions are included, we calculate the correct APE for the interaction terms following the procedure outlined by Ai and Norton (2003) and implemented by Norton et al. (2004).

Our previous findings on FINSHARE are all broadly confirmed. Control variables maintain their sign and significance, except for the coefficient on the provincial value added that in some specifications is no longer significantly different from zero. More importantly, once we control for the organizational structure of the local banking system, the non-monotonic effect of $H H I$ on the probability of firms borrowing on a relational

\footnotetext{
${ }^{16}$ We also estimated a fractional polynomial of degree three, but the results did not significantly differ from those reported with two power terms.
} 
base tends to vanish. Fiercer interbank competition is beneficial to relationship lending only when small, mutual banks are significantly present in the local credit market. Conversely, the predominance of large and functionally distant banks may not be at odds with the use of relationship lending technology only if competition in the credit market is sufficiently low (i.e. $H H I>1$ ).

\subsection{Alternative measures for credit market variables}

Beside bank size and organization, the theoretical and empirical literature has suggested other characteristics of local credit markets as possible drivers of bank orientation. In particular, bank interaction across local credit markets would be a factor facilitating coordination amongst rival banks and restraining price undercutting competition (Heggestad and Rhoades, 1976; Bernheim and Whinston, 1990 $)^{17}$. If this is true, then, following the rationale of the investment theory of relationship banking, banks may have incentives to invest in relation-specific assets in order to establish exclusive ties with borrowers (Anand and Galetovic, 2006).

Recently, Degryse and Ongena (2007) corroborated this theoretical prediction finding that multiple contacts of banks across markets are positively associated with the probability of relationship lending. We therefore augmented model (1) with the inclusion of a provincial measure of multi-market contacts $(M M C)$ that, for reasons of comparability, exactly follows Degryse and Ongena (2007, pp. 408-409) ${ }^{18}$. $M M C$ is strongly correlated with market concentration and with the organizational variables: correlation indexes computed by provinces are 0.56 with $H H I, 0.16$ with $F-D I S T A N C E, 0.46$ with $L A R G E B A N K S$ and -0.48 with $M U T U A L B A N K S$, all statistically significant at the 5 percent level.

For the sake of space, we only report results for the basic specification, without interaction terms (Table 7, columns 1 and 4). The effect of of $M M C$ on relationship lending is not statistically different from zero and its inclusion does not affect the other coefficients $^{19}$. Even if in contrast with the evidence discussed by Degryse and Ongena (2007), this result is consistent with the lack of evidence supporting the multi-market contact hypothesis in the Italian banking market (De Bonis and Ferrando, 2000).

Further robustness checks concern the definitions of functional distance and size structure of the local banking system. So far, we have assumed that agency problems inside the

\footnotetext{
${ }^{17}$ Multi-market contacts may also have pro-competitive effects, because banks may strategically decide to lend more than the optimal level in one market to reduce competition in others (Mester, 1987) or because of their funding advantages (Park and Pennacchi, 2009).

${ }^{18}$ In their turn, Degryse and Ongena follow Evans and Kessides (1994), who suggest calculating $M C C$ as the sum of all bank pairs in the borrower's credit market (in our case the province) weighted by the relative frequency of their bilateral contacts in other markets (provinces):

$$
M M C_{j}=\frac{2}{95 \cdot f_{j} \cdot\left(f_{j}-1\right)} \sum_{k=1}^{B} \sum_{l=k+1}^{B} a_{k, l} D_{k, j} D_{l, j}
$$

where $i=1, \ldots, B$ are the banks, $j=1, \ldots, 95$ are the provinces, $f_{j}$ is the number of banks operating in province $j, D_{i, j}=1$ if bank $i$ operates in province $\mathrm{j}$, and $a_{k, l}=\sum_{j=1}^{B} D_{k, j} D_{l, j}$.

${ }^{19}$ This is also true when we include interactions between $H H I$ and bank organizational variables and even when we consider the interacted term $H H I \times M M C$.
} 
bank organization which makes relationship lending more costly increases with physical distance between the loan officer and the headquarter. However, organizational diseconomies also depend on the branch-headquarter cultural distance, i.e., on trust, norms and cultural affinities between local loan officers and bank's managers at the parent bank (Alessandrini et al., 2008). In this view, we build an alternative measure of functional distance $\left(F-D I S T A N C E_{-} S C\right)$ according to which bank branches are weighted by the difference in social capital between the provinces where the branch and its headquarter are located (Alessandrini et al., 2009b) ${ }^{20}$.

A second refinement relates to the bank-asset threshold used to define the size structure of the local banking system. In particular, we replicate regressions substituting $L A R G E B A N K S$ with MEDIUM BANKS, the share of branches in the province owned by medium-sized banks, where a bank is classified as medium if its total assets are more than 9 billion euros at 2003 prices (see above footnote 11).

As shown in Table 7, columns 2-3 and 5-6, estimation results are virtually unchanged with regard both to the banking and the firm-specific variables. It is worth noting, however, that the importance of functional distance of the local banking system in promoting relationship lending and in shaping the effect of market concentration is higher when it is measured in terms of social capital rather than in terms of kilometers. By contrast, the effects of the size of the local banking system on relationship lending are found to be lower when we include medium banks in the size index.

\subsection{An alternative measure for market competition}

By measuring market rivalry with the Herfindhal-Hirschmann index, we have implicitly espoused a structural approach to competition on the track of the structure-conductperformance paradigm. In reaction to the theoretical flaws of this paradigm, the so-called New Empirical Industrial Organization literature has suggested measuring the degree of competition in the market by looking at the (estimated) behavior of firms. In particular, a widely used non-structural measure of competition is the $H$-statistic introduced by Panzar and Rosse $(1987)^{21}$.

The $H$-statistic is the sum of the elasticities of a bank's revenues $(\mathrm{R})$ with respect to $m$ input prices (w),

$$
H=\sum_{k=1}^{m} \frac{\partial R}{\partial w_{k}} \frac{w_{k}}{R}
$$

and, on real data, it is calculated by summing the estimated coefficients of a log-log reduced form revenue equation. Under the assumption that the market is in a longrun equilibrium, Panzar and Rosse (1987) prove that values of the statistic $H \leq 0$ are

\footnotetext{
${ }^{20}$ To be precise, social capital is computed as the average voter turnout at the 21 referenda held in Italy in 1993, 1995 and 2001 as published by the Home Department. The same results hold if we use the number of blood bags per million population voluntarily donated in each province to the Italian Association of Blood Donors (AVIS) in 1995 (Guiso et al., 2004b).

${ }^{21}$ In the banking literature, the $H$-statistic has been recently employed, amongst others, by Bikker and Haaf (1998), Claessens and Laeven (2005), and, with regard to Italy, by Agostino and Trivieri (2009) and Coccorese (2009).
} 
consistent with the case of firms operating as monopolists or under a monopolistic cartel, values $0<H<1$ are consistent with the case of monopolistic competition and $H=1$ with the case of perfect competition.

In this paper we draw the $H$-statistic $(H-S T A T)$ at the provincial level in 1998 and 2001 from Agostino and Trivieri (2009) ${ }^{22}$. Then, we build three dummy variables for perfectly competitive, imperfectly competitive and monopolistic credit markets, respectively: (i) $H-S T A T_{P C}$ which assumes the value of 1 when we cannot reject the null that the sum of price elasticities is equal to one; (ii) $H-S T A T_{M C}$ which assumes the value of 1 when we reject at $10 \%$ level of confidence the null hypotheses that the sum of the estimated price elasticities of revenue is equal to zero (i.e., $H-S T A T=0$ ) and equal to one (i.e., $H-S T A T=1$ ); (iii) $H-S T A T_{M}$ which assumes the value of 1 when we cannot reject the null that the sum of price elasticities is equal to zero ${ }^{23}$.

Estimation results are reported in Table 8, where $H-S T A T_{P C}$ is taken as the reference category. First, the stability of all our findings relative to control and bank organizational variables testifies that our model of relationship banking is robust to the measure of interbank competition. Second, the coefficients on $H-S T A T_{M C}$ and $H-S T A T_{M}$ are both positive, highly significant and virtually identical in magnitude (columns 1 and 5). Consistent with the investment theory of relationship lending, this result indicates that interbank competition reduces the possibility and/or the convenience of establishing exclusive ties with borrowers and lend on a relational base. However, when we consider the interplay between competition and the organizational structure of the local banking system (columns 2-4 and 6-8), we also have clear confirmation that the beneficial impact of bank market power on relationship lending only holds in markets where the presence of large and functionally distant banks predominates (the interaction terms between the $H-S T A T_{M}$ dummy and MUTUAL BANKS has the right negative sign but is not statistically significant). On average, the share of credit supplied by the main bank is 2.5 percentage points larger in monopolistic than in competitive markets. This effect vanishes in local credit markets with a small share (15\%) of branches owned by large banks and where banks are functionally close, while it is twice as large in credit markets with a dominant share of branches belonging to large banks $(46 \%)$ or to functionally distant banks ( $F-D I S T A N C E$ equal to the third quartile of its provincial distribution).

\section{Concluding remarks}

The current global financial crisis is affecting the structure of local credit markets, via government interventions and bank mergers and acquisitions, and it is bringing exclusive and stable lending relationships with borrowers back to the center of banks' business models. Relationship-based technologies appear to be of great value both for banks,

\footnotetext{
${ }^{22}$ We thank Mariarosaria Agostino and Francesco Trivieri for sharing their dataset and estimation procedure generously with us. Refer to their paper for details on the revenue equations at the provincial level and on the statistical validation of the long-run equilibrium assumption.

${ }^{23}$ On the base of the Vesala's (1995) demonstration that the $H$-statistic is increasing with demand elasticities, in the few cases in which the F-statistics did not reject both the hypotheses of equality to one and equality to zero of price elasticities, we considered the provincial credit market as perfectly competitive, imperfectly competitive or monopolistic according to whether $H-S T A T<0.25,0.25 \leq$ $H-S T A T \geq 0.75$, or $H-S T A T>0.75$.
} 
which are refocusing their activities on their core business, and for small-medium enterprises (SMEs), whose financial needs are more urgent in times of widespread distress ${ }^{24}$. However, deregulation and improvement in communication technologies has also made credit markets more competitive, the incidence of large and geographically dispersed banks more pervasive and transactional lending more profitable. Is relationship lending going to survive these changes? How does interbank competition and the organizational structure of local banking systems affect the exclusiveness of bank-firm relationships?

Theoretical predictions on the impact of interbank competition on relationship lending are contrasting. According to the investment theory of relationship lending, as the credit market concentration increases, the firms' borrowing options shrink, giving banks the opportunity to recoup in the course of the lending relationship the specific investments needed to build extensive ties with a firm. On the other hand, following the strategic theory of relationship lending, fiercer interbank competition drives local lenders to take advantage of their specific knowledge of local economies as a competitive edge, reorienting their lending activity towards relational-based loans to small, local firms.

Hence, to establish whether relationship lending can survive competition is essentially an empirical matter. In two recent papers, Elsas (2005) and Degryse and Ongena (2007) documented a non-linear U-shaped effect of market concentration on relationship lending which cannot be easily accommodated with theory. In this paper we show that this nonmonotonicity can be explained by the organizational structure of local credit markets. Marginal increases in interbank competition are detrimental to relationship lending in markets where large and out-of-market banks are predominant. On the contrary, where relational-based lending technologies are already widely in use in the market by a large group of small mutual banks, an increase in competition may drive banks to further cultivate their extensive ties with customers.

\section{References}

Aghion, P. and Tirole, J. (1997). Formal and real authority in organizations. Journal of Political Economy, 105(1), 1-29.

Agostino, M. and Trivieri, F. (2009). Is banking competition beneficial to smes? an empirical study based on Italian data. Small Business Economics, forthcoming.

Ai, C. and Norton, E. C. (2003). Interaction terms in logit and probit models. Economics Letters, 80(1), 123-129.

Akhavein, J., Frame, W., and White, L. J. (2005). The diffusion of financial innovations: An examination of the adoption of small business credit scoring by large banking organizations. Journal of Business, 78(2), 577-596.

Alessandrini, P., Croci, M., and Zazzaro, A. (2005). The geography of banking power: the role of functional distance. BNL Quarterly Review, LVIII(235), 129-67.

\footnotetext{
${ }^{24}$ On the value of relationship lending on Korean SMEs during the 1997 financial crisis, see Ferri et al. (2001).
} 
Alessandrini, P., Calcagnini, G., and Zazzaro, A. (2008). Asset restructuring strategies in bank acquisitions: Does distance between dealing partners matter? Journal of Banking \& Finance, 32(5), 699-713.

Alessandrini, P., Presbitero, A. F., and Zazzaro, A. (2009a). Bank Size or Distance: What Hampers Innovation Adoption by SMEs? Journal of Economic Geography, forthcoming.

Alessandrini, P., Presbitero, A. F., and Zazzaro, A. (2009b). Banks, distances and firms' financing constraints. Review of Finance, 13(2), 261-307.

Anand, B. N. and Galetovic, A. (2006). Relationships, competition and the structure of investment banking markets. Journal of Industrial Economics, 54(2), 151-199.

Angelini, P., Di Salvo, R., and Ferri, G. (1998). Availability and cost of credit for small businesses: Customer relationships and credit cooperatives. Journal of Banking $\&$ Finance, 22(6-8), 925-954.

Benfratello, L., Schiantarelli, F., and Sembenelli, A. (2008). Banks and innovation: Microeconometric evidence on Italian firms. Journal of Financial Economics, 90, 197-217.

Benvenuti, M., Casolaro, L., Del Prete, S., and Mistrulli, P. E. (2009). Loan officer authority and small business lending. evidence from a survey. paper presented at the MoFiR conference "The Changing Geography of Money, Banking and Finance in a Post-Crisis World"' (Ancona), available at http://changingeography09.univpm.it/.

Berger, A. N. and Udell, G. F. (1996). Universal banking and the future of small business lending. In A. Saunders and I. Walter, editors, Universal Banking: Financial System Design Reconsidered. Irwin, Burr Ridge, IL.

Berger, A. N. and Udell, G. F. (2002). Small business credit availability and relationship lending: The importance of bank organisational structure. The Economic Journal, 112(477), F32-F53.

Berger, A. N. and Udell, G. F. (2006). A more complete conceptual framework for sme finance. Journal of Banking \& Finance, 30(477), 2945-2966.

Berger, A. N., Demsetz, R. S., and Strahan, P. E. (1999). The consolidation of the financial services industry: Causes, consequences, and implications for the future. Journal of Banking \& Finance, 23(2-4), 135-194.

Berger, A. N., Miller, N. H., Petersen, M. A., Rajan, R. G., and Stein, J. C. (2005). Does function follow organizational form? Evidence from the lending practices of large and small banks. Journal of Financial Economics, 76(2), 237-269.

Berger, A. N., Rosen, R. J., and Udell, G. F. (2007). Does market size structure affect competition? The case of small business lending. Journal of Banking $\& 5$ Finance, 31(1), $11-33$.

Bernheim, B. D. and Whinston, M. D. (1990). Multimarket contact and collusive behavior. RAND Journal of Economics, 21(1), 1-26. 
Bikker, J. A. and Haaf, K. (1998). Competition, concentration and their relationship: An empirical analysis of the banking industry. Journal of Banking E Finance, 26(11), 2192-2214.

Bond, S., Harhoff, D., and Van Reenen, J. (2003). Investment, R\&D and financial constraints in britain and germany. CEP Discussion Papers dp0595, Centre for Economic Performance, LSE.

Boot, A. W. A. and Thakor, A. V. (2000). Can relationship banking survive competition? Journal of Finance, 55(2), 679-713.

Bresnahan, T. F. (1989). Empirical studies of industries with market power. In R. Schmalensee and R. Willig, editors, Handbook of Industrial Organization, volume 2 of Handbook of Industrial Organization, chapter 17, pages 1011-1057. Elsevier.

Brevoort, K. P. and Hannan, T. H. (2004). Commercial lending and distance: evidence from Community Reinvestment Act data. Finance and Economics Discussion Series 24, Federal Reserve Board.

Canales, R. and Nanda, R. (2008). Bank structure and terms of lending to small firms. Working Paper 8, Harvard Business School.

Capitalia (2005). Indagine sulle imprese manifatturiere. Nono Rapporto sull'industria italiana e sulla politica industriale. Capitalia, Roma.

Carbó-Valverde, S., Rodríguez-Fernández, F., and Udell, G. F. (2009). Bank market power and sme financing constraints. Review of Finance, 13(2), 309-340.

Carter, D. A. and McNulty, J. E. (2005). Deregulation, technological change, and the business-lending performance of large and small banks. Journal of Banking 6 Finance, 29(5), 1113-1130.

Cetorelli, N. (1999). Competitive analysis in banking: appraisal of the methodologies. Federal Reserve Bank of Chicago Economic Perspectives, (Q I), 2-15.

Cetorelli, N. and Strahan, P. E. (2006). Finance as a barrier to entry: Bank competition and industry structure in local u.s. markets. Journal of Finance, 61(1), 437-461.

Claessens, S. and Laeven, L. (2005). Financial development, banking sector competition, and economic growth. Journal of the European Economic Association, 3(1), 179-207.

Coccorese, P. (2009). Market power in local banking monopolies. Journal of Banking \& Finance, 33(7), 1196-1210.

Cole, R. A., Goldberg, L. G., and White, L. J. (2004). Cookie-cutter versus character: The micro structure of small business lending by large and small banks. Journal of Financial and Quantitative Analysis, 39(2), 227-251.

Cosci, S. and Meliciani, V. (2002). Multiple banking relationships: evidence from the italian experience. The Manchester School, 70(0), 37-54. 
De Bonis, R. and Ferrando, A. (2000). The italian banking structure in the 1990s: Testing the multimarket contact hypothesis. Economic Notes, 29(2), 215-241.

De Bonis, R., Ferri, G., and Rotondi, Z. (2008). Firms' internationalization and relationship with banks. In G. Bracchi and D. Masciandaro, editors, Banche italiane e governo dei rischi. Imprese, famiglie, regole. Bancaria Editrice, Roma.

Degryse, H. and Ongena, S. (2007). The impact of competition on bank orientation. Journal of Financial Intermediation, 16(3), 399-424.

Degryse, H., Laeven, L., and Ongena, S. (2009a). The impact of organizational structure and lending technology on banking competition. Review of Finance, 13(1), 225-259.

Degryse, H., Masschelein, N., and Mitchell, J. (2009b). Staying, dropping, or switching: the impacts of bank mergers on small firms. Review of Financial Studies, forthcoming.

Delgado, J., Salas, V., and Saurina, J. (2007). Joint size and ownership specialization in bank lending. Journal of Banking \& Finance, 31(12), 3563-3583.

Dell'Ariccia, G. and Marquez, R. (2004). Information and bank credit allocation. Journal of Financial Economics, 72(1), 185-214.

Dinc, I. S. (2000). Bank reputation, bank commitment, and the effects of competition in credit markets. Review of Financial Studies, 13(5), 781-812.

Dwyer, D. W., Kocagil, A. E., and Stein, R. M. (2004). Moody's KMV RISKCALC ${ }^{T M}$ v3.1 Model. Next-generation technology for predicting private firm credit risk. Available at http : //www.moodyskmv.com/products/files/riskcalc_v3_1_model.pdf, Moody's KMV.

Elsas, R. (2005). Empirical determinants of relationship lending. Journal of Financial Intermediation, 14(1), 32-57.

Evans, W. N. and Kessides, I. N. (1994). Living by the "golden rule": Multimarket contact in the US airline industry. Quarterly Journal of Economics, 109(2), 341-366.

Ferri, G. and Messori, M. (2000). Bank-firm relationships and allocative efficiency in northeastern and central Italy and in the south. Journal of Banking $\mathscr{E}$ Finance, 24(6), $1067-1095$.

Ferri, G., Kang, T. S., and Kim, I.-J. (2001). The value of relationship banking during financial crises : evidence from the republic of korea. Policy Research Working Paper Series 2553, The World Bank.

Fischer, K.-H. (2000). Acquisition of information in loan markets and bank market power - An empirical investigation. Goethe University Frankfurt.

Frame, W., Srinivasan, A., and Woosley, L. (2001). The effect of credit scoring on small business lending. Journal of Money Credit and Banking, 33(3), 813-825. 
Garicano, L. (2000). Hierarchies and the organization of knowledge in production. Journal of Political Economy, 108(5), 874-904.

Guiso, L. and Minetti, R. (2004). Multiple creditors and information rights: theory and evidence from us firms. CEPR Discussion Paper 4278, CEPR.

Guiso, L., Sapienza, P., and Zingales, L. (2004a). Does local financial development matter? The Quarterly Journal of Economics, 119(3), 929-969.

Guiso, L., Sapienza, P., and Zingales, L. (2004b). The role of social capital in financial development. The American Economic Review, 94(3), 526-556.

Hausman, J. A. and Leonard, G. K. (1997). Superstars in the national basketball association: Economic value and policy. Journal of Labor Economics, 15(4), 586-624.

Hauswald, R. and Marquez, R. (2006). Competition and Strategic Information Acquisition in Credit Markets. Review of Financial Studies, 19(3), 967-1000.

Heggestad, A. A. and Rhoades, S. A. (1976). Concentration and firm stability in commercial banking. The Review of Economics and Statistics, 58(4), 443-52.

Herrera, A. M. and Minetti, R. (2007). Informed finance and technological change: Evidence from credit relationships. Journal of Financial Economics, 83(1), 223-269.

Hertzberg, A., Liberti, J. M., and Paravisini, D. (2009). Information and incentives inside the firm: Evidence from loan officer rotation. Journal of Finance, forthcoming.

Liberti, J. M. and Mian, A. R. (2009). Estimating the effect of hierarchies on information use. Review of Financial Studies, 22(10), 4057-4090.

Lucchetti, R., Papi, L., and Zazzaro, A. (2001). Banks' inefficiency and economic growth: A micro-macro approach. The Scottish Journal of Political Economy, 48(4), 400-424.

Marsh, L. C. and Cormier, D. R. (2002). Spline Regression Models. Quantitative Applications in the Social Sciences. Sage Publications, Thousand Oaks.

Memmel, C., Schmieder, C., and Stein, I. (2007). Relationship lending: empirical evidence for Germany. Discussion Paper Series 2: Banking and Financial Studies 14, Deutsche Bundesbank.

Mester, L. J. (1987). Multiple market contact between savings and loans: A note. Journal of Money, Credit and Banking, 19(4), 538-49.

Mian, A. (2006). Distance constraints: The limits of foreign lending in poor economies. The Journal of Finance, LXI(3), 1465-1505.

Micucci, G. and Rossi, P. (2009). Debt restructuring and the role of lending technologies. paper presented at the MoFiR conference "The Changing Geography of Money, Banking and Finance in a Post-Crisis World"' (Ancona), available at http://changingeography09.univpm.it/. 
Milbourn, T. T., Shockley, R. L., and Thakor, A. V. (2001). Managerial career concerns and investments in information. RAND Journal of Economics, 32(2), 334-51.

Moulton, B. R. (1990). An illustration of a pitfall in estimating the effects of aggregate variables on micro unit. The Review of Economics and Statistics, 72(2), 334-38.

Neuberger, D., Pedergnana, M., and Räthke-Döppner, S. (2008). Concentration of banking relationships in Switzerland: The result of firm structure or banking market structure? Journal of Financial Services Research, 33(2), 101-126.

Norton, E. C., Wang, H., and Ai, C. (2004). Computing interaction effects and standard errors in logit and probit models. Stata Journal, 4(2), 154-167.

Ogura, Y. (2007). Lending competition, relationship banking, and credit availability for entrepreneurs. Discussion papers 07036, Research Institute of Economy, Trade and Industry (RIETI).

Ogura, Y. (2009). Interbank competition and information production: Evidence from the interest rate difference. Journal of Financial Intermediation, doi:10.1016/j.jfi.2009.09.001.

Ongena, S. and Smith, D. C. (2000). What determines the number of bank relationships? Cross-country evidence. Journal of Financial Intermediation, 9(1), 26-56.

Panzar, J. C. and Rosse, J. N. (1987). Testing for "Monopoly" Equilibrium. Journal of Industrial Economics, 35(4), 443-56.

Papke, L. E. and Wooldridge, J. M. (1996). Econometric methods for fractional response variables with an application to 401(k) plan participation rates. Journal of Applied Econometrics, 11(6), 619-32.

Park, K. and Pennacchi, G. (2009). Harming depositors and helping borrowers: The disparate impact of bank consolidation. Review of Financial Studies, 22(1), 1-40.

Petersen, M. A. (2009). Estimating standard errors in finance panel data sets: Comparing approaches. Review of Financial Studies, 22(1), 435-480.

Petersen, M. A. and Rajan, R. G. (1995). The effect of credit market competition on lending relationships. The Quarterly Journal of Economics, 110(2), 407-43.

Rajan, R. G. (1992). Insiders and outsiders: The choice between informed and arm'slength debt. Journal of Finance, 47(4), 1367-400.

Rice, T. and Strahan, P. E. (2009). Does credit competition affect small-firm finance? Journal of Finance, forthcoming.

Royston, P. and Sauerbrei, W. (2008). Multivariable Model-building: A Pragmatic Approach to Regression Analysis Based on Fractional Polynomials for Modelling Continuous Variables. Wiley, Chichester, UK. 
Sapienza, P. (2002). The effects of banking mergers on loan contracts. Journal of Finance, 57(1), 329-367.

Scharfstein, D. S. and Stein, J. C. (2000). The dark side of internal capital markets: Divisional rent-seeking and inefficient investment. Journal of Finance, 55(6), 25372564.

Scott, J. (2004). Small business and the value of community financial institutions. Journal of Financial Services Research, 25(2), 207-230.

Sharpe, S. A. (1990). Asymmetric information, bank lending, and implicit contracts: A stylized model of customer relationships. Journal of Finance, 45(4), 1069-87.

Stein, J. C. (2002). Information production and capital allocation: Decentralized versus hierarchical firms. Journal of Finance, 57(5), 1891-1921.

Uchida, H., Udell, G. F., and Watanabe, W. (2008). Bank size and lending relationships in Japan. Journal of the Japanese and International Economies, 22(2), 242-267.

Uzzi, B. (1999). Embeddedness in the making of financial capital: How social relations and networks benefit firms seeking financing. American Sociological Review, 64(9), $481-505$.

Vesala, J. (1995). Testing for competition in banking: behavioural evidence from Finland. Working paper E:1, Bank of Finland.

von Thadden, E.-L. (2004). Asymmetric information, bank lending and implicit contracts: the winner's curse. Finance Research Letters, 1(1), 11-23.

Wagner, J. (2001). A note on the firm size-export relationship. Small Business Economics, $\mathbf{1 7}(4), 229-37$.

Yafeh, Y. and Yosha, O. (2001). Industrial Organization of Financial Systems and Strategic Use of Relationship Banking. European Finance Review, 5(1-2), 63-78. 
A Tables 
Table 1: Definition of variables and sample statistics

\begin{tabular}{|c|c|c|c|}
\hline Variable Name & Variable Definition & Mean & St.Dev. \\
\hline \multicolumn{4}{|c|}{ DEPENDENT VARIABLES } \\
\hline FINSHARE & $\begin{array}{l}\text { The share of banking credit supplied to the firm by its main bank. } \\
\text { Source: Unicredit Surveys. }\end{array}$ & 0.404 & 0.199 \\
\hline$R E L B A N K(0,1)$ & $\begin{array}{l}=1 \text { if the firm obtains at least } 20 \text { per cent of banking credit from its main } \\
\text { bank and has credit lines with no more than five banks. Source: Unicredit } \\
\text { Surveys. }\end{array}$ & 0.596 & 0.496 \\
\hline \multicolumn{4}{|c|}{ MARKET ORGANIZATIONAL STRUCTURE VARIABLES } \\
\hline$H H I$ & $\begin{array}{l}\text { Summed squares of bank market shares by number of branches in the } \\
\text { province (ranging from } 0 \text { to } 10 \text { ). Source: Bank of Italy. }\end{array}$ & 1.119 & 0.493 \\
\hline$F-D I S T A N C E$ & $\begin{array}{l}\text { The ratio of branches weighted by the logarithm of } 1 \text { plus the kilometric } \\
\text { distance between the province of the branch and that where the parent } \\
\text { bank is headquartered, over total branches in the province. See also } \\
\text { footnote } 9 \text {. Source: Bank of Italy. }\end{array}$ & 2.731 & 0.876 \\
\hline$L A R G E B A N K S$ & $\begin{array}{l}\text { The ratio of branches owned by large banks (assets }>€ 26 \text { bn) to the } \\
\text { total number of branches operating in each province. Source: Bank of Italy. }\end{array}$ & 32.378 & 16.203 \\
\hline$M U T U A L B A N K S$ & $\begin{array}{l}\text { The ratio of branches owned by mutual banks to the total number of } \\
\text { branches operating in each province. Source: Bank of Italy. }\end{array}$ & 10.148 & 8.864 \\
\hline$H-S T A T$ & $\begin{array}{l}\text { The Panzar-Rosse } H \text {-statistic calculated at the provincial level. It is } \\
\text { divided into three categories: monopoly }(\mathrm{M}, H-S T A T \leq 0) \text {, monopolistic } \\
\text { competition (MC, } 0<H-S T A T<1) \text { and perfect competition (PC, } \\
H-S T A T=1) \text {. Source: Agostino and Trivieri }(2009) \text {. }\end{array}$ & 0.414 & 0.350 \\
\hline$F-D I S T A N C E \_S C$ & $\begin{array}{l}\text { The ratio of branches weighted by the logarithm of } 1 \text { plus the cultural } \\
\text { distance between the province of the branch and that where the parent } \\
\text { bank is headquartered, over total branches in the province. See also } \\
\text { footnote } 22 \text {. Source: Bank of Italy. }\end{array}$ & 0.856 & 0.451 \\
\hline$M E D I U M B A N K S$ & $\begin{array}{l}\text { The ratio of branches owned by medium banks (assets }>€ 9 \mathrm{bn} \text { ) to the } \\
\text { total number of branches operating in each province. Source: Bank of Italy. }\end{array}$ & 59.722 & 19.176 \\
\hline$M M C$ & $\begin{array}{l}\text { A measure of multi-market contacts. See Degryse and Ongena (2007). } \\
\text { Source: Bank of Italy. }\end{array}$ & 0.241 & 0.127 \\
\hline \multicolumn{4}{|c|}{ Control variables } \\
\hline$S I Z E$ & $\begin{array}{l}\text { The number of firm's workers, divided into four categories: } 11-20,21-50, \\
51-250,251-499 \text { employees. Source: Unicredit Surveys. }\end{array}$ & 61.563 & 75.307 \\
\hline RISK & The firm's one-year risk of default. Source: RiskCalc ${ }^{T M}$ (Dwyer et al., 2004) & 0.013 & 0.021 \\
\hline$A G E$ & $\begin{array}{l}\text { The logarithm of } 1 \text { plus the years from the firm's inception. Source: } \\
\text { Unicredit Surveys. }\end{array}$ & 3.079 & 0.651 \\
\hline ISO9000 $(0,1)$ & $\begin{array}{l}=1 \text { if the firm is ISO } 9000 \text { certified by the International Organization } \\
\text { for Standardization. Source: Unicredit Surveys. }\end{array}$ & 0.471 & 0.499 \\
\hline$R \& D(0,1)$ & $\begin{array}{l}=1 \text { if the firm made expenditures on Research and Development in the } \\
\text { three-year period covered by each survey. Source: Unicredit Surveys. }\end{array}$ & 0.435 & 0.496 \\
\hline OFFSHORE $(0,1)$ & $\begin{array}{l}=1 \text { if the firm realizes part of its production abroad. Source: Unicredit } \\
\text { Surveys. }\end{array}$ & 0.046 & 0.210 \\
\hline EXPORT $(0,1)$ & $\begin{array}{l}=1 \text { if the firm sells part of its production abroad. Source: Unicredit } \\
\text { Surveys. }\end{array}$ & 0.717 & 0.450 \\
\hline$V A L U E A D D E D$ & $\begin{array}{l}\text { the logarithm of the provincial real per capita value added in the year } \\
\text { before the survey. Source: ISTAT (National Institute of Statistics). }\end{array}$ & 9.879 & 0.241 \\
\hline
\end{tabular}

Notes: Elaboration over the sample drawn from the Eight and Ninth Surveys of Manufacturing Firms (Capitalia, 2005).

The number of observations amounts to 4,121 . 
Table 2: Distribution of FINSHARE and RELBANK across $H H I$

\begin{tabular}{lccc}
\hline & FINSHARE & RELBANK & Obs. \\
\cline { 2 - 4 }$H H I=1^{\circ}$ quintile & 0.407 & 0.590 & 830 \\
$H H I=2^{\circ}$ quintile & 0.396 & $0.521^{* *}$ & 856 \\
$H H I=3^{\circ}$ quintile & 0.398 & $0.543^{*}$ & 808 \\
$H H I=4^{\circ}$ quintile & 0.402 & 0.565 & 823 \\
$H H I=5^{\circ}$ quintile & $0.429^{*}$ & $0.641^{*}$ & 804 \\
\hline Whole sample & 0.406 & 0.571 & 4,121 \\
\hline
\end{tabular}

Notes: Numbers are obtained considering the sample of 4,121 firms used in the regression analysis. FINSHARE is the share of bank credit supplied to the firm by its main bank. RELBANK is a dummy variable which identifies firms that borrow at least 20 percent of credit from the main bank and have contacts with no more than 5 banks. $\left({ }^{* *}\right)(*)$ indicate statistical significance at the $1 \%(5 \%)$ level of a two-tailed test of the null that the values of the $2{ }^{\circ}-5^{\circ}$ quintiles of FINSHARE and RELBANK are equal to their values at the first quintile of the HHI distribution.

Table 3: Pairwise correlation

\begin{tabular}{lcccc}
\hline & $H H I$ & LARGE BANKS & F-DISTANCE & MUTUAL BANKS \\
\cline { 2 - 4 } HHI & 1.000 & & & \\
LARGE BANKS & -0.039 & 1.000 & & \\
F-DISTANCE & $0.179^{*}$ & $0.350^{*}$ & 1.000 & 1.000 \\
MUTUAL BANKS & $-0.312^{*}$ & $-0.262^{*}$ & $-0.394^{*}$ & \\
\hline
\end{tabular}

Notes: Elaboration over the sample of 95 provinces and the sample period 1998-2003. $\left({ }^{*}\right)$ indicates statistical significance at the $5 \%$ level. 


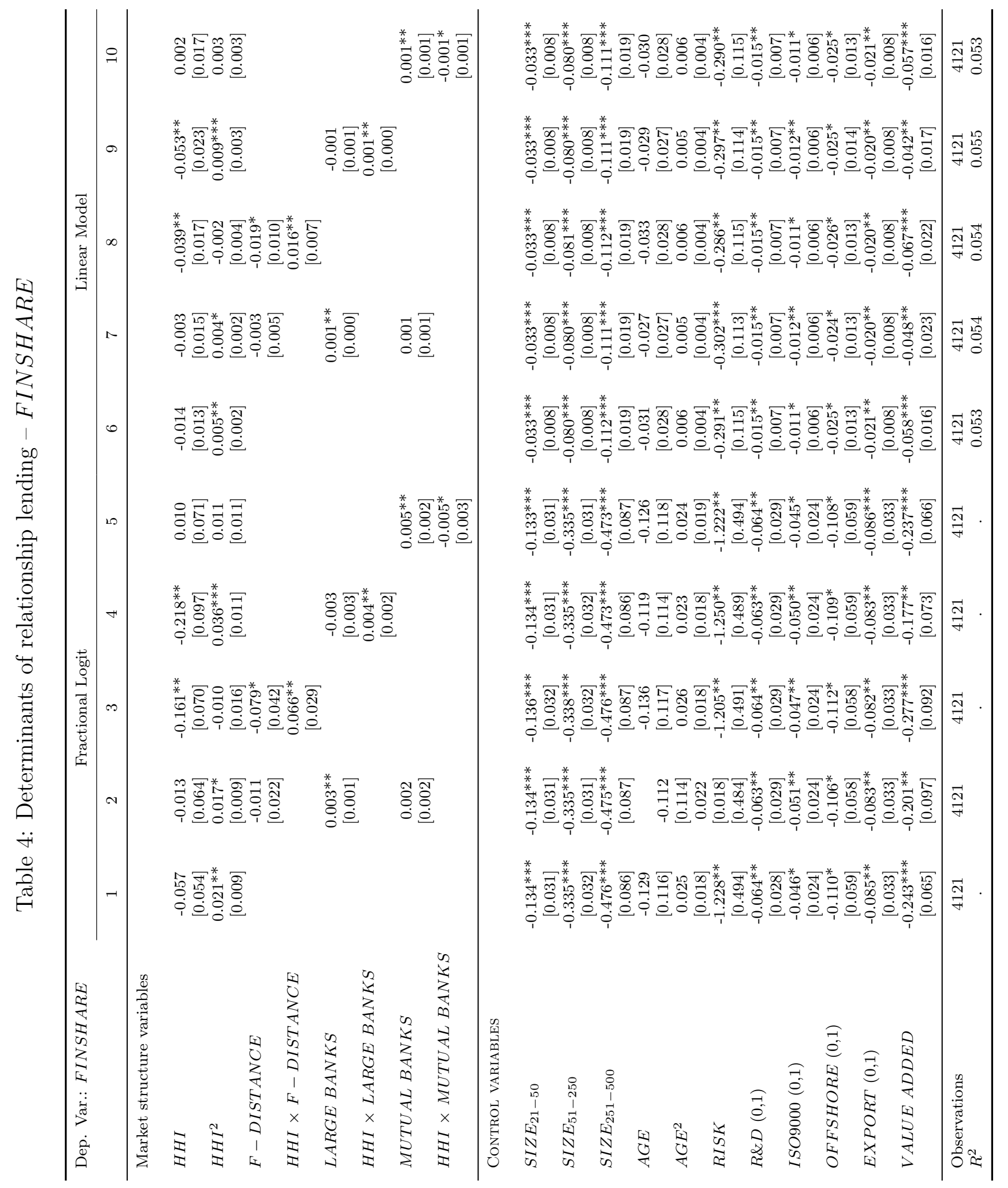


Notes to Table 4: The table reports regression coefficients and, in brackets, the associated standard errors, clustered at provincial level. * significant at $10 \% ; * *$ significant at $5 \%$;** significant at $1 \%$. The model is estimated by fractional logit, using the Stata 10 SE package with GLM command, in columns (1-5) and by OLS, using the Stata 10 SE package with REG command, in columns (6-10). The dependent variable is the share of bank credit supplied to the firm by its main bank (FINSHARE). The variable SIZE is split into four categories, with the reference category being $11-20$ employees. All regressions include industry and time dummies and a constant, not reported for reasons of space. 
Table 5: Alternative testing for non-linearities

\begin{tabular}{|c|c|c|c|c|}
\hline \multirow[t]{2}{*}{ Dep. Var.: FINSHARE } & \multicolumn{2}{|c|}{ Fractional Logit } & \multicolumn{2}{|c|}{ Linear Model } \\
\hline & 1 & 2 & 3 & 4 \\
\hline \multicolumn{5}{|c|}{ MARKET STRUCTURE VARIABLES } \\
\hline$H H I_{<0.975}$ & $\begin{array}{c}-0.170^{* *} \\
{[0.082]}\end{array}$ & & $\begin{array}{c}-0.041^{* *} \\
{[0.020]}\end{array}$ & \\
\hline$H H I_{>0.975}$ & $\begin{array}{c}0.065^{* *} \\
{[0.028]}\end{array}$ & & $\begin{array}{c}0.016^{* *} \\
{[0.007]}\end{array}$ & \\
\hline$H H I^{-2}$ & & $\begin{array}{l}0.021^{*} \\
{[0.011]}\end{array}$ & & $\begin{array}{l}0.005^{*} \\
{[0.003]}\end{array}$ \\
\hline$H H I^{2}$ & & $\begin{array}{c}0.013^{* * *} \\
{[0.003]}\end{array}$ & & $\begin{array}{c}0.003^{* * *} \\
{[0.001]}\end{array}$ \\
\hline \multicolumn{5}{|l|}{ Control variables } \\
\hline$S I Z E_{21-50}$ & $\begin{array}{c}-0.135^{* * *} \\
{[0.031]}\end{array}$ & $\begin{array}{c}-0.135^{* * *} \\
{[0.031]}\end{array}$ & $\begin{array}{c}-0.033^{* * * *} \\
{[0.008]}\end{array}$ & $\begin{array}{c}-0.033^{* * *} \\
{[0.008]}\end{array}$ \\
\hline$S I Z E_{51-250}$ & $\begin{array}{c}-0.335^{* * * *} \\
{[0.032]}\end{array}$ & $\begin{array}{c}-0.335^{* * * *} \\
{[0.032]}\end{array}$ & $\begin{array}{c}-0.080 * * * \\
{[0.008]}\end{array}$ & $\begin{array}{c}-0.080 * * * \\
{[0.008]}\end{array}$ \\
\hline$S I Z E_{251-500}$ & $\begin{array}{c}-0.477^{* * *} \\
{[0.087]}\end{array}$ & $\begin{array}{c}-0.475^{* * *} \\
{[0.086]}\end{array}$ & $\begin{array}{c}-0.112^{* * *} \\
{[0.019]}\end{array}$ & $\begin{array}{c}-0.111^{* * *} \\
{[0.019]}\end{array}$ \\
\hline$A G E$ & $\begin{array}{l}-0.119 \\
{[0.115]}\end{array}$ & $\begin{array}{l}-0.126 \\
{[0.116]}\end{array}$ & $\begin{array}{l}-0.028 \\
{[0.028]}\end{array}$ & $\begin{array}{l}-0.030 \\
{[0.028]}\end{array}$ \\
\hline$A G E^{2}$ & $\begin{array}{c}0.023 \\
{[0.018]}\end{array}$ & $\begin{array}{c}0.024 \\
{[0.018]}\end{array}$ & $\begin{array}{c}0.006 \\
{[0.004]}\end{array}$ & $\begin{array}{c}0.006 \\
{[0.004]}\end{array}$ \\
\hline$R I S K$ & $\begin{array}{c}-1.246^{* *} \\
{[0.490]}\end{array}$ & $\begin{array}{c}-1.238^{* *} \\
{[0.493]}\end{array}$ & $\begin{array}{c}-0.296^{* *} \\
{[0.114]}\end{array}$ & $\begin{array}{c}-0.294^{* *} \\
{[0.115]}\end{array}$ \\
\hline$R \& D(0,1)$ & $\begin{array}{c}-0.063^{* *} \\
{[0.029]}\end{array}$ & $\begin{array}{c}-0.063^{* *} \\
{[0.029]}\end{array}$ & $\begin{array}{c}-0.015^{* *} \\
{[0.007]}\end{array}$ & $\begin{array}{c}-0.015^{* *} \\
{[0.007]}\end{array}$ \\
\hline ISO9000 $(0,1)$ & $\begin{array}{c}-0.047^{*} \\
{[0.024]}\end{array}$ & $\begin{array}{c}-0.046^{*} \\
{[0.024]}\end{array}$ & $\begin{array}{c}-0.011^{*} \\
{[0.006]}\end{array}$ & $\begin{array}{c}-0.011^{*} \\
{[0.006]}\end{array}$ \\
\hline OFFSHORE $(0,1)$ & $\begin{array}{c}-0.109^{*} \\
{[0.059]}\end{array}$ & $\begin{array}{c}-0.109^{*} \\
{[0.058]}\end{array}$ & $\begin{array}{c}-0.025^{*} \\
{[0.013]}\end{array}$ & $\begin{array}{c}-0.025^{*} \\
{[0.013]}\end{array}$ \\
\hline EXPORT $(0,1)$ & $\begin{array}{c}-0.083^{* *} \\
{[0.033]}\end{array}$ & $\begin{array}{c}-0.085^{* *} \\
{[0.033]}\end{array}$ & $\begin{array}{c}-0.020^{* *} \\
{[0.008]}\end{array}$ & $\begin{array}{c}-0.021^{* *} \\
{[0.008]}\end{array}$ \\
\hline$V A L U E A D D E D$ & $\begin{array}{c}-0.242^{* * *} \\
{[0.063]}\end{array}$ & $\begin{array}{c}-0.248^{* * *} \\
{[0.065]}\end{array}$ & $\begin{array}{c}-0.058^{* * *} \\
{[0.015]}\end{array}$ & $\begin{array}{c}-0.060^{* * * *} \\
{[0.016]}\end{array}$ \\
\hline $\begin{array}{l}\text { Observations } \\
R^{2}\end{array}$ & 4121 & 4121 & $\begin{array}{l}4121 \\
0.053\end{array}$ & $\begin{array}{l}4121 \\
0.053\end{array}$ \\
\hline
\end{tabular}

Notes to Table 5: The table reports regression coefficients and, in brackets, the associated standard errors, clustered at provincial level. * significant at $10 \%$; ${ }^{*}$ significant at $5 \% ;{ }^{* *}$ significant at $1 \%$. The model is estimated by fractional logit, using the Stata 10 SE package with GLM command, in columns (1-2) and by OLS, using the Stata 10 SE package with REG command, in columns (3-4). The fractional polynomial model with two power terms (columns 2 and 4) is estimated using also the FRACPOLY command. The dependent variable is the share of bank credit supplied to the firm by its main bank (FINSHARE). The variable SIZE is split into four categories, with the reference category being 11-20 employees. $H H I_{<0.975}$ and $H H I_{>0.975}$ refer, respectively, to the linear spline for values of $H H I$ below and above the threshold set at 0.975. All regressions include industry and time dummies and a constant, not reported for reasons of space. 


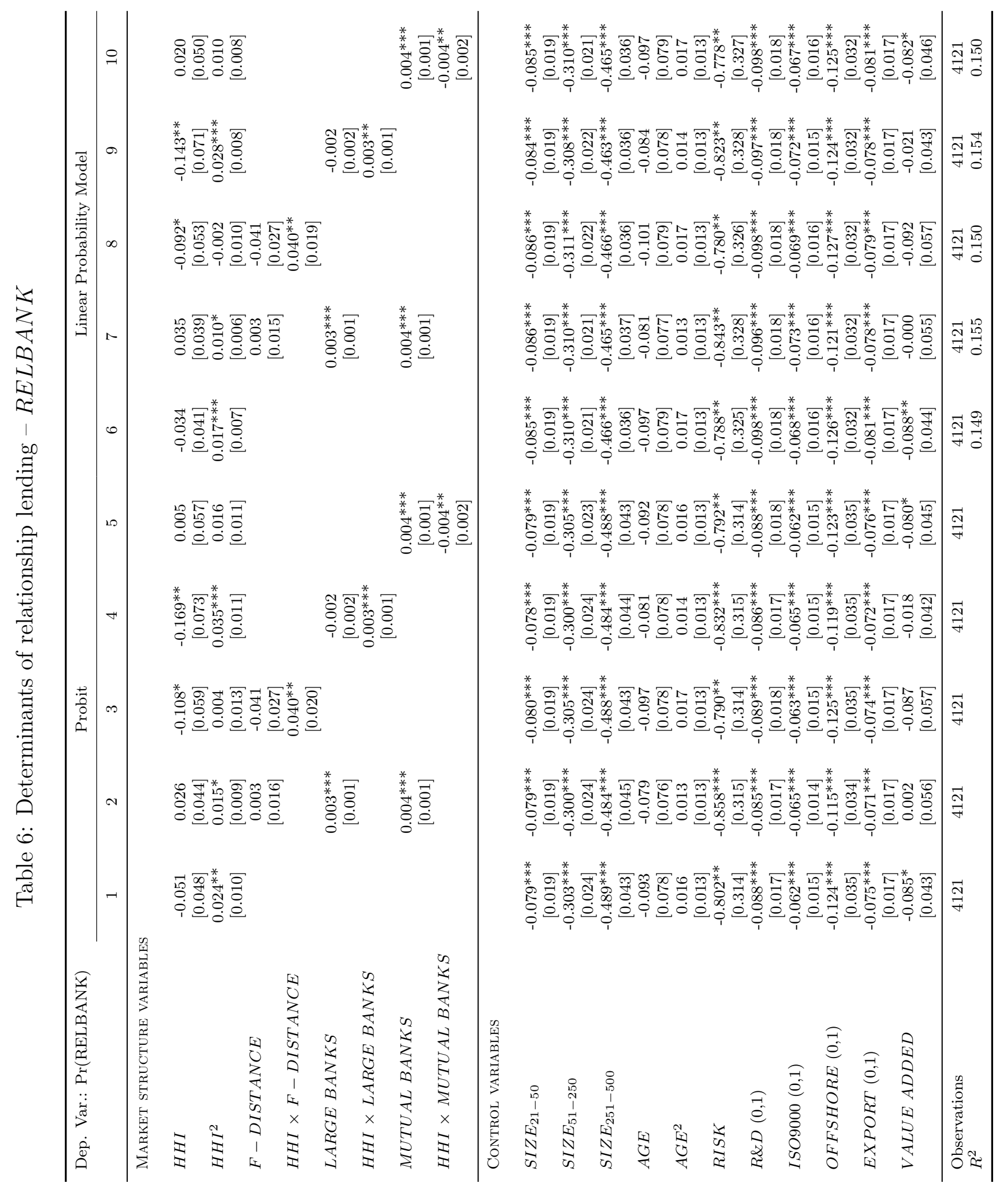


Notes to Table 6: The table reports average partial effects in columns (1-5) and regression coefficients in columns (610) The associated standard errors, in brackets, are clustered at provincial level. * significant at $10 \%$; $* *$ significant at $5 \%$; *** significant at $1 \%$. The model is estimated by probit, using the Stata $10 \mathrm{SE}$ package with PROBIT command, in columns (1-5) and by OLS, using the Stata $10 \mathrm{SE}$ package with REG command, in columns (6-10). The average partial effects reported in columns (1-4) are computed at sample means using the MARGEFF command, while the marginal effects of the interaction terms (columns 2-4) are computed by the INTEFF command (Norton et al., 2004). The dependent variable $(R E L B A N K)$ is a dummy equal to one if the firm obtains at least one fifth of banking credit from its main bank and has credit lines with no more than five banks. The variable $S I Z E$ is split into four categories, with the reference category being 11-20 employees. All regressions include industry and time dummies and a constant, not reported for reasons of space. 
Table 7: Alternative market structure variables

\begin{tabular}{|c|c|c|c|c|c|c|}
\hline \multirow[t]{2}{*}{ Dep. Var.: FINSHARE } & \multicolumn{3}{|c|}{ Fractional Logit } & \multicolumn{3}{|c|}{ Linear Model } \\
\hline & 1 & 2 & 3 & 4 & 5 & 6 \\
\hline \multicolumn{7}{|l|}{ MARKET STRUCTURE VARIABLES } \\
\hline$H H I$ & $\begin{array}{l}-0.035 \\
{[0.065]}\end{array}$ & $\begin{array}{c}-0.109^{* *} \\
{[0.052]}\end{array}$ & $\begin{array}{c}-0.141^{* *} \\
{[0.063]}\end{array}$ & $\begin{array}{l}-0.009 \\
{[0.016]}\end{array}$ & $\begin{array}{c}-0.027^{* *} \\
{[0.013]}\end{array}$ & $\begin{array}{c}-0.035^{* *} \\
{[0.015]}\end{array}$ \\
\hline$H H I^{2}$ & $\begin{array}{l}0.018^{* *} \\
{[0.009]}\end{array}$ & $\begin{array}{l}-0.012 \\
{[0.016]}\end{array}$ & $\begin{array}{c}0.002 \\
{[0.015]}\end{array}$ & $\begin{array}{l}0.005^{* *} \\
{[0.002]}\end{array}$ & $\begin{array}{l}-0.003 \\
{[0.004]}\end{array}$ & $\begin{array}{c}0.000 \\
{[0.004]}\end{array}$ \\
\hline$M M C$ & $\begin{array}{l}-0.087 \\
{[0.155]}\end{array}$ & & & $\begin{array}{l}-0.021 \\
{[0.037]}\end{array}$ & & \\
\hline$F-D I S T A N C E \_S C$ & & $\begin{array}{c}-0.240 * * \\
{[0.094]}\end{array}$ & & & $\begin{array}{c}-0.058^{* *} \\
{[0.022]}\end{array}$ & \\
\hline$H H I \times F-D I S T A N C E_{-} S C$ & & $\begin{array}{c}0.143^{* *} \\
{[0.056]}\end{array}$ & & & $\begin{array}{c}0.035^{* *} \\
{[0.014]}\end{array}$ & \\
\hline$M E D I U M B A N K S$ & & & $\begin{array}{l}-0.002 \\
{[0.002]}\end{array}$ & & & $\begin{array}{l}-0.001 \\
{[0.000]}\end{array}$ \\
\hline$H H I \times M E D I U M B A N K S$ & & & $\begin{array}{l}0.002^{*} \\
{[0.001]}\end{array}$ & & & $\begin{array}{l}0.001^{*} \\
{[0.000]}\end{array}$ \\
\hline \multicolumn{7}{|l|}{ Control variables } \\
\hline$S I Z E_{21-50}$ & $\begin{array}{c}-0.135^{* * *} \\
{[0.032]}\end{array}$ & $\begin{array}{c}-0.135 * * * \\
{[0.032]}\end{array}$ & $\begin{array}{c}-0.134^{* * *} \\
{[0.031]}\end{array}$ & $\begin{array}{c}-0.033^{* * *} \\
{[0.008]}\end{array}$ & $\begin{array}{c}-0.033^{* * *} \\
{[0.008]}\end{array}$ & $\begin{array}{c}-0.033^{* * *} \\
{[0.008]}\end{array}$ \\
\hline$S I Z E_{51-250}$ & $\begin{array}{c}-0.336^{* * *} \\
{[0.032]}\end{array}$ & $\begin{array}{c}-0.338^{* * * *} \\
{[0.032]}\end{array}$ & $\begin{array}{c}-0.335 * * * \\
{[0.032]}\end{array}$ & $\begin{array}{c}-0.081^{* * *} \\
{[0.008]}\end{array}$ & $\begin{array}{c}-0.081^{* * *} \\
{[0.008]}\end{array}$ & $\begin{array}{c}-0.080^{* * *} \\
{[0.008]}\end{array}$ \\
\hline$S I Z E_{251-500}$ & $\begin{array}{c}-0.476^{* * *} \\
{[0.086]}\end{array}$ & $\begin{array}{c}-0.474 * * * \\
{[0.086]}\end{array}$ & $\begin{array}{c}-0.475 * * * \\
{[0.087]}\end{array}$ & $\begin{array}{c}-0.112^{* * * *} \\
{[0.019]}\end{array}$ & $\begin{array}{c}-0.111^{* * *} \\
{[0.019]}\end{array}$ & $\begin{array}{c}-0.111^{* * *} \\
{[0.019]}\end{array}$ \\
\hline$A G E$ & $\begin{array}{l}-0.130 \\
{[0.116]}\end{array}$ & $\begin{array}{l}-0.132 \\
{[0.117]}\end{array}$ & $\begin{array}{l}-0.128 \\
{[0.116]}\end{array}$ & $\begin{array}{l}-0.031 \\
{[0.028]}\end{array}$ & $\begin{array}{l}-0.032 \\
{[0.028]}\end{array}$ & $\begin{array}{l}-0.031 \\
{[0.028]}\end{array}$ \\
\hline$A G E^{2}$ & $\begin{array}{c}0.025 \\
{[0.018]}\end{array}$ & $\begin{array}{c}0.025 \\
{[0.018]}\end{array}$ & $\begin{array}{c}0.024 \\
{[0.018]}\end{array}$ & $\begin{array}{l}0.006 \\
{[0.004]}\end{array}$ & $\begin{array}{c}0.006 \\
{[0.004]}\end{array}$ & $\begin{array}{c}0.006 \\
{[0.004]}\end{array}$ \\
\hline$R I S K$ & $\begin{array}{c}-1.227^{* *} \\
{[0.493]}\end{array}$ & $\begin{array}{c}-1.234^{* *} \\
{[0.499]}\end{array}$ & $\begin{array}{c}-1.212^{* *} \\
{[0.495]}\end{array}$ & $\begin{array}{c}-0.291^{* *} \\
{[0.115]}\end{array}$ & $\begin{array}{c}-0.292^{* *} \\
{[0.117]}\end{array}$ & $\begin{array}{c}-0.287^{* *} \\
{[0.116]}\end{array}$ \\
\hline$R \& D(0,1)$ & $\begin{array}{c}-0.064^{* *} \\
{[0.028]}\end{array}$ & $\begin{array}{c}-0.063^{* *} \\
{[0.029]}\end{array}$ & $\begin{array}{c}-0.064^{* *} \\
{[0.029]}\end{array}$ & $\begin{array}{c}-0.015^{* *} \\
{[0.007]}\end{array}$ & $\begin{array}{c}-0.015^{* *} \\
{[0.007]}\end{array}$ & $\begin{array}{c}-0.015^{* *} \\
{[0.007]}\end{array}$ \\
\hline ISO9000 $(0,1)$ & $\begin{array}{c}-0.047^{*} \\
{[0.024]}\end{array}$ & $\begin{array}{c}-0.046^{*} \\
{[0.024]}\end{array}$ & $\begin{array}{c}-0.046^{*} \\
{[0.024]}\end{array}$ & $\begin{array}{c}-0.011^{*} \\
{[0.006]}\end{array}$ & $\begin{array}{c}-0.011^{*} \\
{[0.006]}\end{array}$ & $\begin{array}{c}-0.011^{*} \\
{[0.006]}\end{array}$ \\
\hline OFFSHORE $(0,1)$ & $\begin{array}{c}-0.110^{*} \\
{[0.058]}\end{array}$ & $\begin{array}{c}-0.112^{*} \\
{[0.059]}\end{array}$ & $\begin{array}{c}-0.110^{*} \\
{[0.059]}\end{array}$ & $\begin{array}{c}-0.025^{*} \\
{[0.013]}\end{array}$ & $\begin{array}{c}-0.026^{*} \\
{[0.013]}\end{array}$ & $\begin{array}{c}-0.025^{*} \\
{[0.013]}\end{array}$ \\
\hline EXPORT $(0,1)$ & $\begin{array}{c}-0.085^{* *} \\
{[0.033]}\end{array}$ & $\begin{array}{c}-0.084^{* *} \\
{[0.033]}\end{array}$ & $\begin{array}{c}-0.086^{* *} \\
{[0.033]}\end{array}$ & $\begin{array}{c}-0.021^{* *} \\
{[0.008]}\end{array}$ & $\begin{array}{c}-0.020^{* *} \\
{[0.008]}\end{array}$ & $\begin{array}{c}-0.021^{* *} \\
{[0.008]}\end{array}$ \\
\hline$V A L U E A D D E D$ & $\begin{array}{c}-0.254^{* * * *} \\
{[0.067]} \\
\end{array}$ & $\begin{array}{c}-0.372^{* * *} \\
{[0.103]} \\
\end{array}$ & $\begin{array}{c}-0.236^{* * * *} \\
{[0.064]}\end{array}$ & $\begin{array}{c}-0.061^{* * * *} \\
{[0.016]}\end{array}$ & $\begin{array}{c}-0.089^{* * * *} \\
{[0.025]}\end{array}$ & $\begin{array}{c}-0.056^{* * * *} \\
{[0.016]} \\
\end{array}$ \\
\hline $\begin{array}{l}\text { Observations } \\
R^{2}\end{array}$ & 4121 & $\begin{array}{c}4121 \\
.\end{array}$ & $\begin{array}{c}4121 \\
.\end{array}$ & $\begin{array}{l}4121 \\
0.052\end{array}$ & $\begin{array}{l}4121 \\
0.055\end{array}$ & $\begin{array}{l}4121 \\
0.054\end{array}$ \\
\hline
\end{tabular}

Notes to Table 7: The table reports regression coefficients and, in brackets, the associated standard errors, clustered at provincial level. * significant at $10 \% ; * *$ significant at $5 \% ; * * *$ significant at $1 \%$. The model is estimated by fractional logit, using the Stata 10 SE package with GLM command, in columns (1-4) and by OLS, using the Stata 10 SE package with REG command, in columns (5-8). The dependent variable is the share of bank credit supplied to the firm by its main bank (FINSHARE). The variable SIZE is split into four categories, with the reference category being 11-20 employees. All regressions include industry and time dummies and a constant, not reported for reasons of space. 


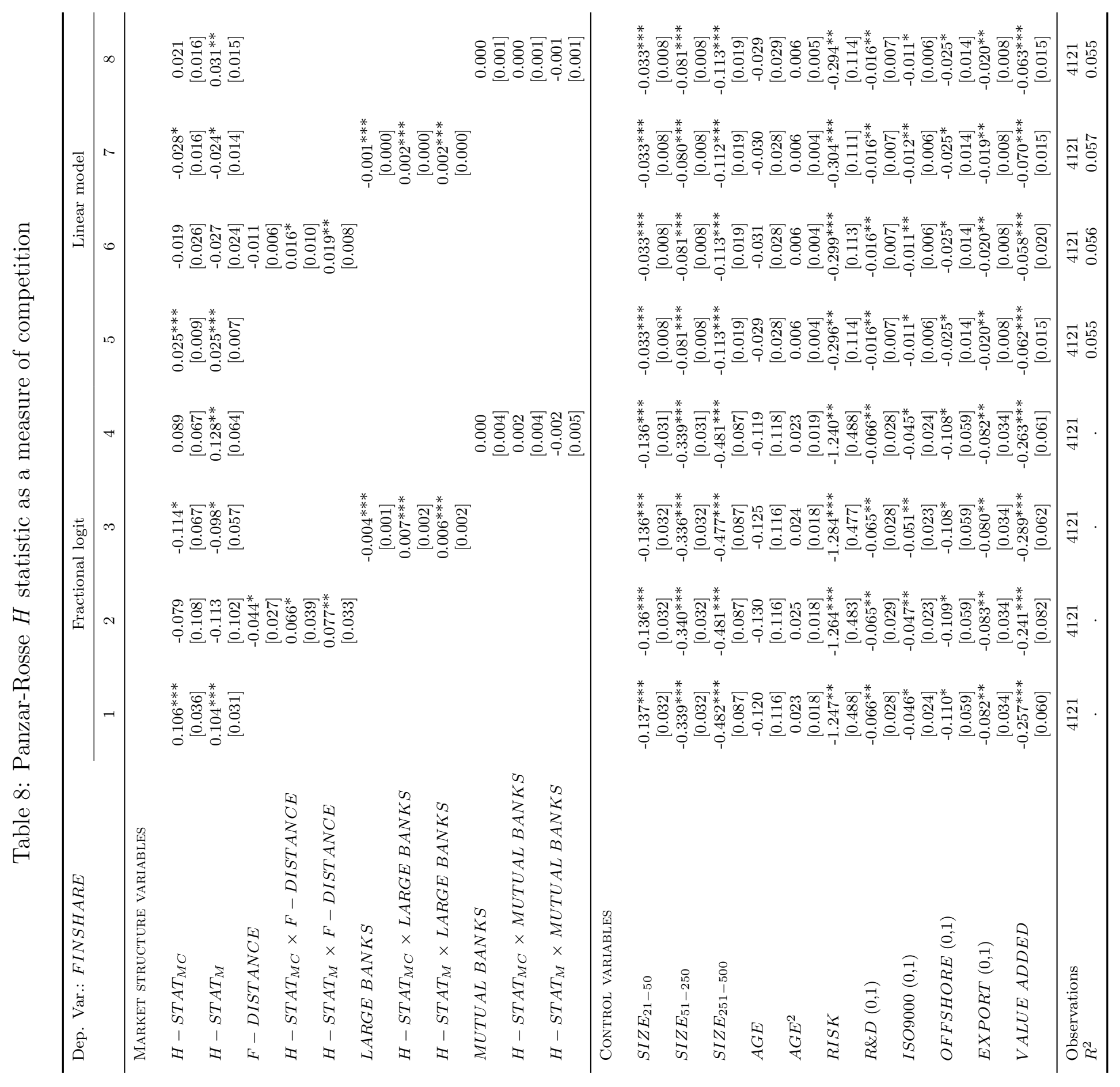


Notes to Table 8: The table reports regression coefficients and, in brackets, the associated standard errors, clustered at provincial level. ${ }^{*}$ significant at $10 \% ;{ }^{* *}$ significant at $5 \% ;{ }^{* *}$ significant at $1 \%$. The model is estimated by fractional logit, using the Stata 10 SE package with GLM command, in columns (1-4) and by OLS, using the Stata 10 SE package with REG command, in columns (5-8). The dependent variable is the share of bank credit supplied to the firm by its main bank (FINSHARE). The variable SIZE is split into four categories, with the reference category being 11-20 employees. $H-S T A T$ is divided into three categories: monopoly (M), monopolistic competition (MC) and perfect competition (PC), with the latter taken as reference category. All regressions include industry and time dummies and a constant, not reported for reasons of space. 


\section{B Figures}

Figure 1: Bank-firm relationships

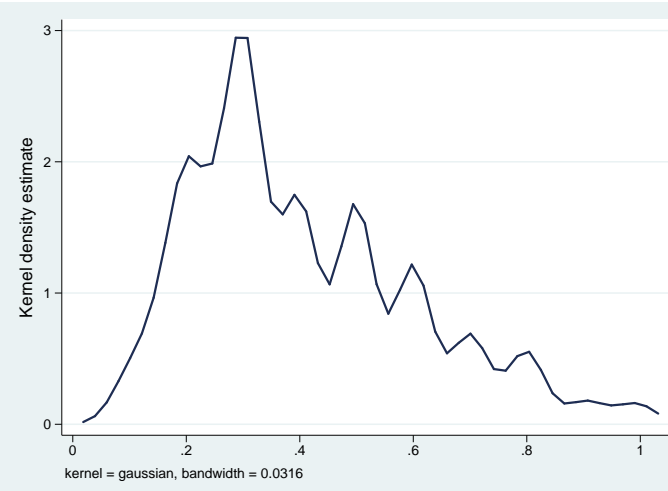

(a) Sample distribution of FINSHARE

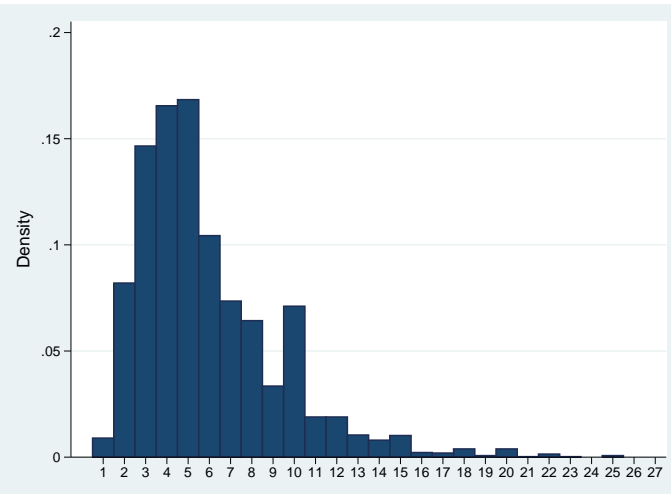

(b) Sample distribution of the number of banks

Notes: Elaboration over the sample of 4,121 firms. FINSHARE is the share of bank credit supplied to the firm by its main bank. 
Figure 2: Market concentration and relationship lending

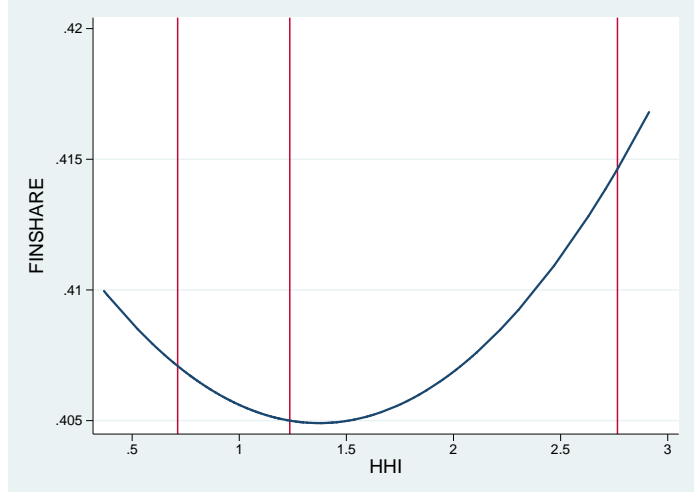

Calculations based on the estimates of Table 4 (column 1). All the control variables are taken at their sample mean. The red vertical lines plot the $5^{\circ}$ percentile, the median and the $95^{\circ}$ percentile of the provincial distribution of $H H I$ over the sample period 1998-2003. 
Figure 3: Market organisational structure, concentration and relationship lending

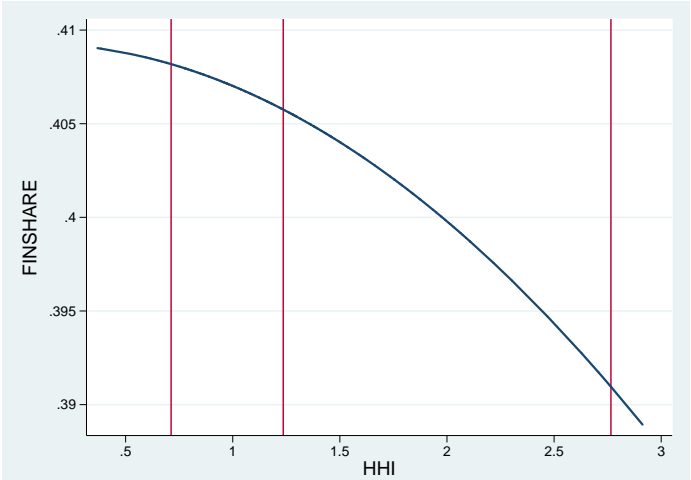

(a) I quartile of $F-D I S T A N C E$

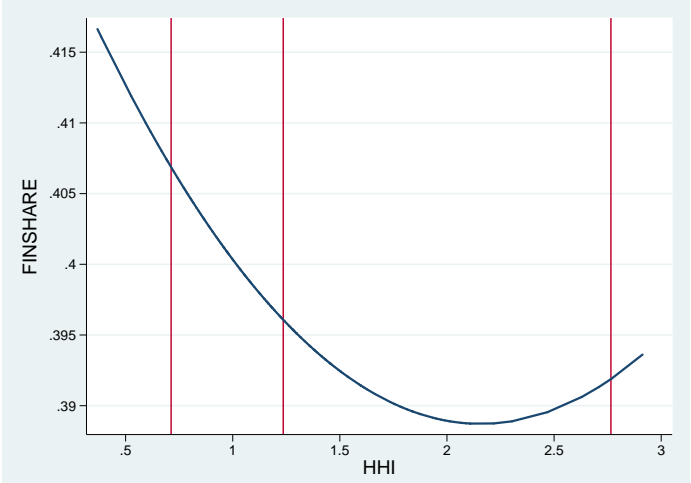

(c) I quartile of $L A R G E B A N K S$

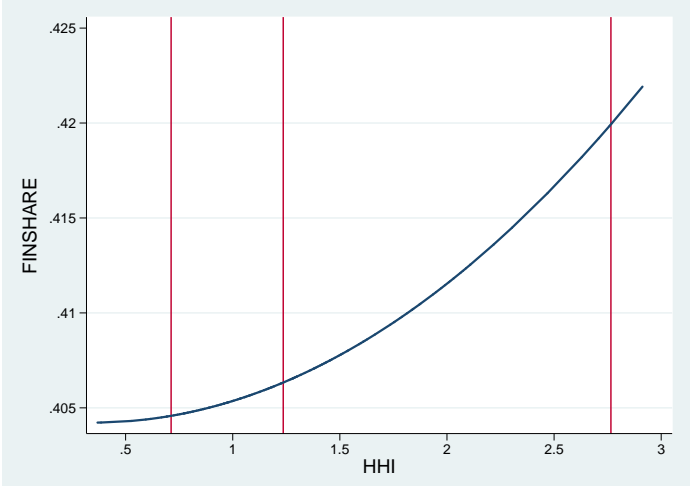

(e) I quartile of $M U T U A L B A N K S$

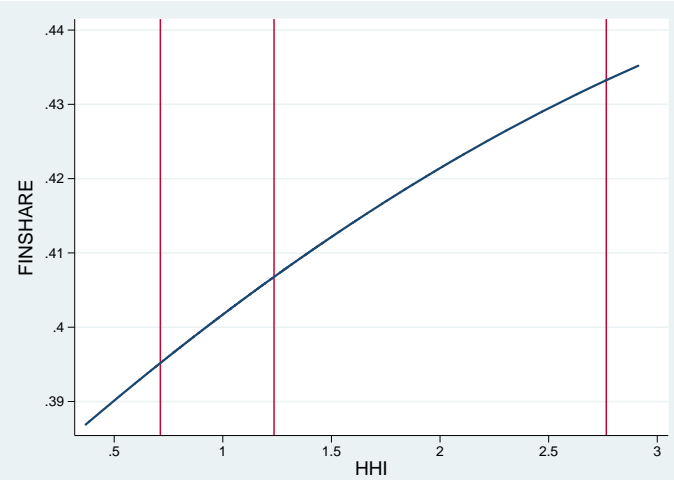

(b) III quartile of $F-D I S T A N C E$

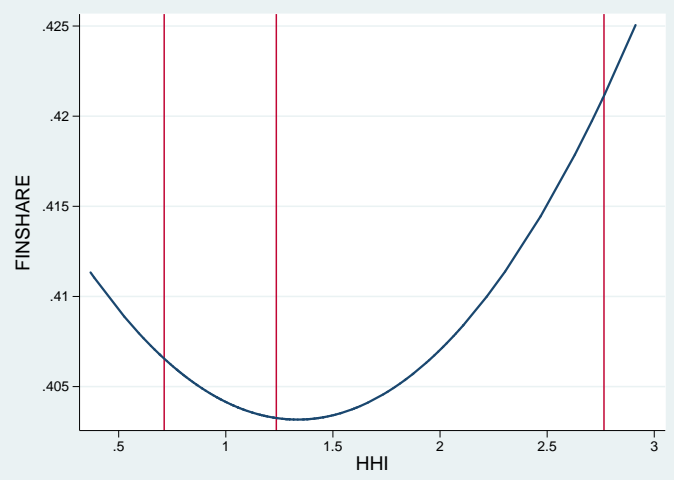

(d) III quartile of $L A R G E B A N K S$

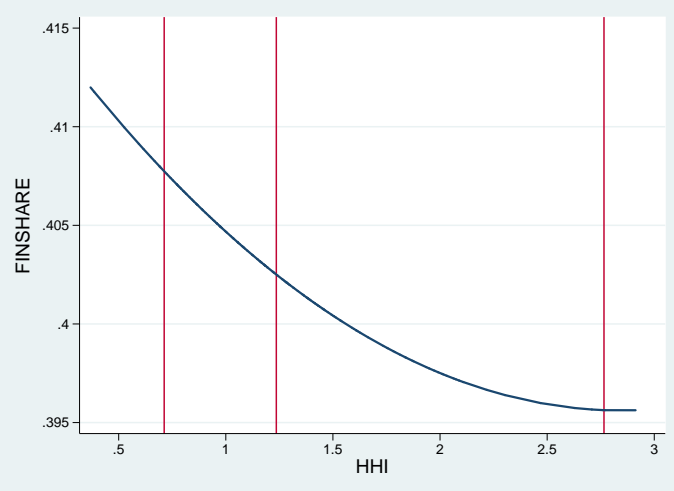

(f) III quartile of $M U T U A L B A N K S$

Notes: Calculations based on the estimates in Table 4 (columns 3 to 5). In the left (right) hand-side diagrams the market structure variables are taken at the first (third) quartile of their provincial distribution over the sample period 1998-2003, while the other variables are taken at their sample mean. The red vertical lines plot the $5^{\circ}$ percentile, the median and the $95^{\circ}$ percentile of the provincial distribution of $H H I$ over the sample period 1998-2003. 
Figure 4: Fractional polynomial models with two power terms

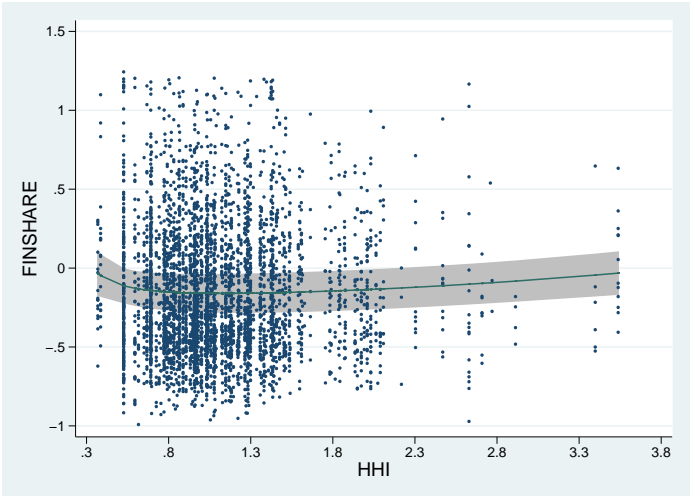

(a) Fractional logit

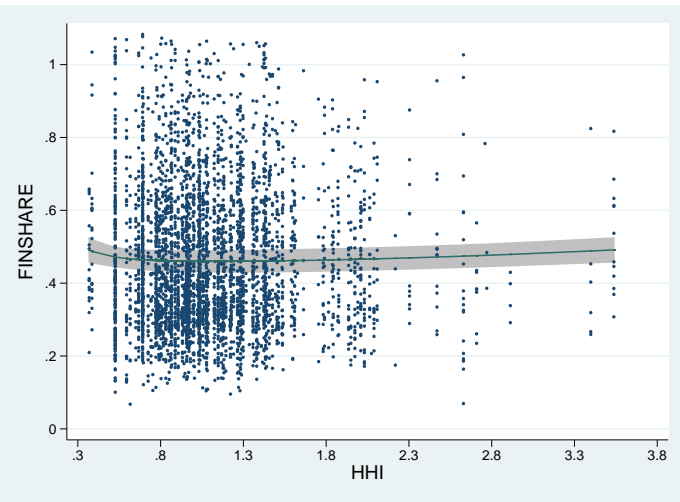

(b) Linear model

Notes: Calculations based on the estimates in Table 5 (columns 2 to 4). Diagrams show the fit and the $95 \%$ confidence interval, adjusted for covariates, resulting from a fractional polynomial model of degree two, estimated by a fractional logit (panel (a)) and a linear model (panel(b)). 